\title{
Mining and Water Pollution
}

\author{
Hlanganani Tutu \\ Molecular Sciences Institute \\ School of Chemistry \\ University of the Witwatersrand, Johannesburg \\ South Africa
}

\section{Introduction}

Residual sulphide minerals, especially pyrite, in the tailings dumps are unstable when exposed to atmospheric oxygen and undergo oxidation resulting in the generation of acid mine drainage (AMD) and the subsequent release of heavy metals and metalloids (Jambor \& Blowes, 1998). The problem of sulphide oxidation and the associated AMD, or more generally acid rock drainage (ARD), as well as the solution and precipitation processes of metals and minerals, has been a major focus of investigation for over half a century (Nordstrom et al., 1979; Morin \& Hutt, 1997; Jambor \& Blowes, 1998; Nordstrom \& Alpers, 1999).

AMD is formed by a series of complex geochemical and microbial reactions. Notwithstanding, these reactions and processes are not yet fully understood and are still subject to ongoing research.

There are four sub-reactions involved in AMD (Singer \& Stumm, 1970), the first reaction being the oxidation of sulphide to sulphate and ferrous ion:

$$
\mathrm{FeS}_{2}+7 / 2 \mathrm{O}_{2}+\mathrm{H}_{2} \mathrm{O} \rightarrow \mathrm{Fe}^{2+}+2 \mathrm{SO}_{4}^{2-}+2 \mathrm{H}^{+}
$$

Penetration of oxygenated water is believed to occur through expansion and contraction of pore-air due to diurnal and seasonal temperature changes. Therefore, erosion of the dumps or any other disturbance which would permit penetration of oxygenated water, for example reworking of the dump poses a potential pollution problem.

Reactions similar to that in (1) involving other sulphide minerals can lead to the dissolution of elements such as $\mathrm{As}, \mathrm{Cu}, \mathrm{Cr}, \mathrm{Ni}, \mathrm{Pb}, \mathrm{Co}$ and $\mathrm{Zn}$ which can be leached into underlying aquifers by percolating rainwater. As groundwater exudes into surface water bodies, ferrous iron undergoes oxidation. This reaction is $\mathrm{pH}$ dependent and proceeds slowly under acidic conditions $(\mathrm{pH} \approx 2-3)$ :

$$
4 \mathrm{Fe}^{2+}+\mathrm{O}_{2}+4 \mathrm{H}^{+} \rightarrow 4 \mathrm{Fe}^{3+}+2 \mathrm{H}_{2} \mathrm{O}
$$

This is the rate-determining step in the overall acid-generating sequence and is dependent on the presence of Thiobacillus ferrooxidans bacteria (which are acidophilic and chemolithotropic), oxygen and $\mathrm{pH}$. 
Neutralising reactions, with mineral phases in rock, often reduce the acidity resulting in a groundwater plume at slightly acidic $\mathrm{pH}$ but containing high concentrations of $\mathrm{Fe}^{2+}$ and $\mathrm{SO}_{4}{ }^{2-}$.

The ferric ion produced in reaction 2 precipitates as ferric hydroxide:

$$
4 \mathrm{Fe}^{3+}+12 \mathrm{H}_{2} \mathrm{O} \rightarrow 4 \mathrm{Fe}(\mathrm{OH})_{3} \downarrow+12 \mathrm{H}^{+}
$$

On losing a water molecule and undergoing structural re-arrangement, the iron hydroxide forms goethite $(\mathrm{FeOOH})$, a common iron(III) oxide.

The fourth reaction involves the oxidation of additional pyrite by ferric ion, $\mathrm{Fe}^{3+}$.

$$
\mathrm{FeS}_{2}+14 \mathrm{Fe}^{3+}+8 \mathrm{H}_{2} \mathrm{O} \rightarrow 15 \mathrm{Fe}^{2+}+2 \mathrm{SO}_{4}^{2-}+16 \mathrm{H}^{+}
$$

This is a self-sustaining reaction and as such renders tailings dumps as sources of AMD for a long time after mining operations have ceased (Nordstrom, 1979; Moses et al., 1987; Ehrlich, 1996; Blowes et al., 1998). This is prevalent in gold and coal mines which are considered to be the main long-term polluters (Pulles, 2003).

There has been less interest in the mineralogical and geochemical interactions taking place within the tailings facilities (Jambor, 1994), yet this is an essential aspect to understand the parameters controlling AMD formation and to develop effective prevention methods. To this end, this work aims at assessing this phenomenon and, based on the results, to draw conclusions about the potential impact this could have on the quality of receiving natural waters. The assessment is based on gold and coal mining case studies (Fig. 1). In the gold mining case, geochemical transformations in two tailings storage facilities (one undergoing reprocessing and the other a decommissioned active slimes dam) were assessed while in the coal mining case these processes were assessed in a decommissioned opencast operation.

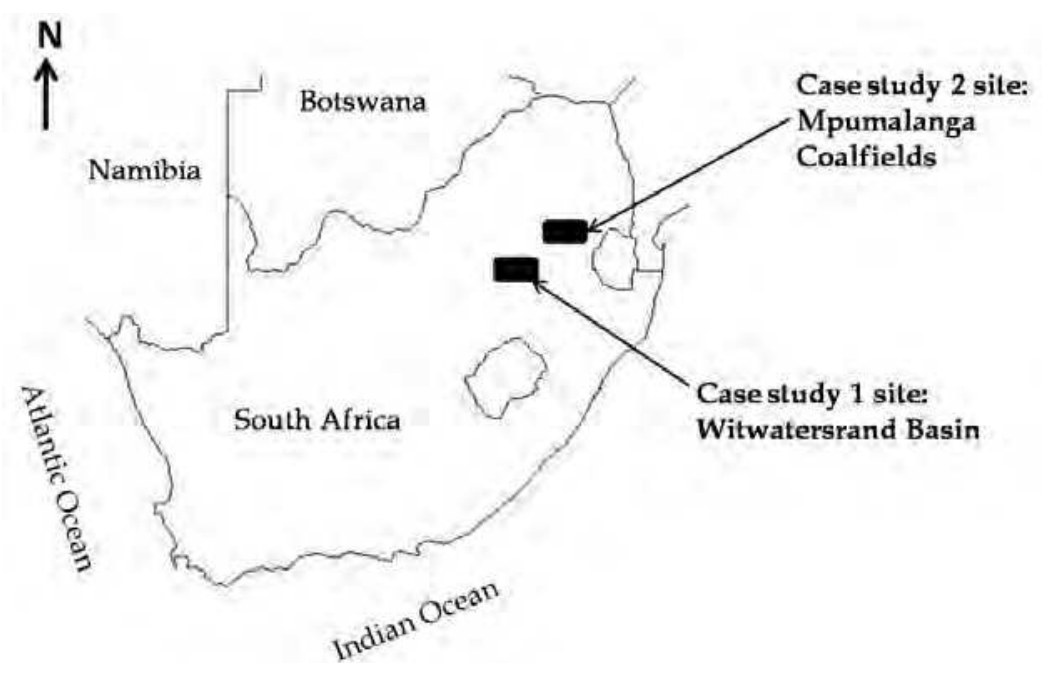

Fig. 1. Location of case study sites. 


\section{Case study 1: Water quality in gold mining operations in the Witwatersrand Basin, South Africa}

The Central Rand goldfield of the Witwatersrand Basin, South Africa has been one of the most important gold mining areas in the world. It is, however, replete with gold mine tailings which have contributed significantly to water pollution as a result of AMD. Water quality is affected mainly by mine tailings and spillages, especially from active slimes dams, reprocessed tailings, as well as from footprints left behind after reprocessing.

Water pollution studies undertaken over the past decade have established good baseline data on the state of the water environment of the Central Rand. Water quality information from the Rand Water Board, Water Research Commission and Crown Gold Recovery shows that the drainage systems on the East and Central Rand have been affected by AMD and have high salt loads (Forstner \& Wittmann, 1976; Marsden, 1986; Jones et al., 1988; Scott, 1995; Rosner \& van Schalkwyk, 2000; Rosner et al., 2001; Davidson, 2003; Mphephu, 2004).

In this work, column leaching experiments are introduced to simulate (at a laboratory scale) the leaching process occurring in the tailings storage facilities (TSFs). They provide a conceptual approach to understanding the chemical weathering of the minerals in the tailings and the subsequent leaching of the constituents that pose a potential pollution threat to surface and ground water systems.

\subsection{Sampling and analytical protocol}

Tailings for column leaching were collected from a TSF undergoing reprocessing (Fig. 2).

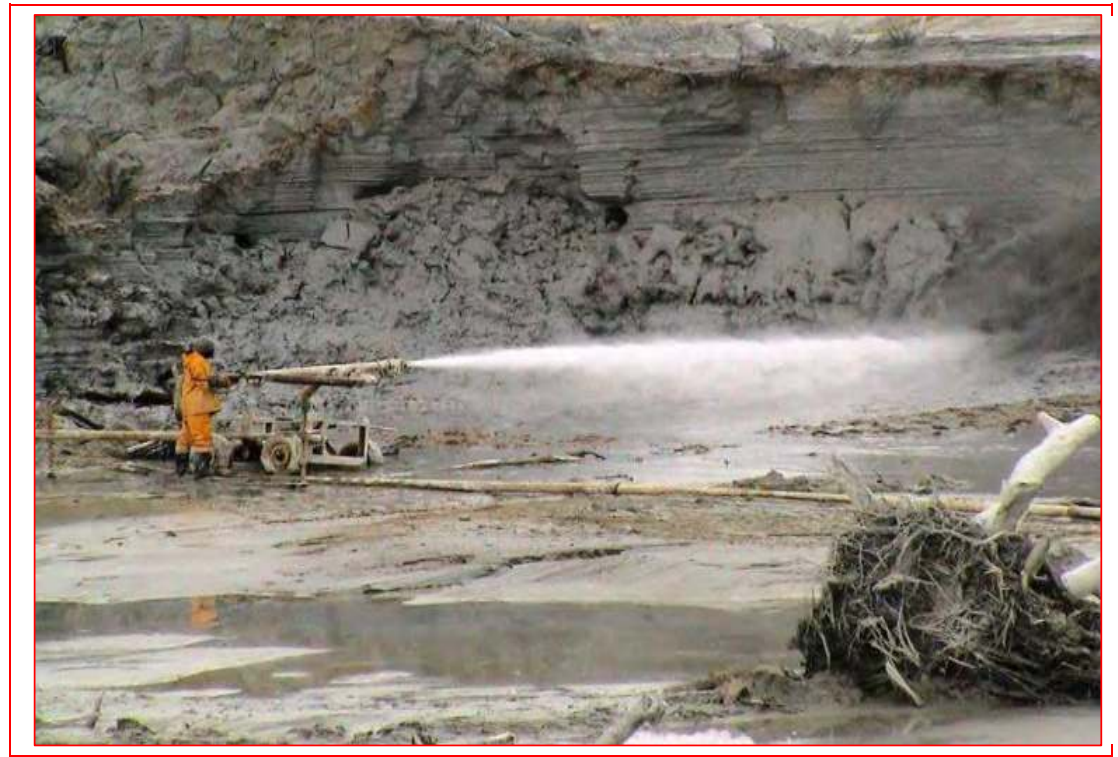

Fig. 2. Monitoring method being used for preparing slimes tailings for reprocessing at Crown Mines. 
The yellowish oxidised layers were scrapped off and the dark-greyish (unoxidised) tailings sampled. $\mathrm{pH}$ was measured by inserting a probe into the moist tailings. The material was homogenised and packed into columns ( $80 \mathrm{~cm}$ length $\times 4.5 \mathrm{~cm}$ width) in the laboratory. A small quantity was dried and used to determine the pore volume which is the volume of water required to fill up the pore spaces in the material. Pore volume is the amount or volume of water needed to replace water in a certain volume of saturated porous media. In this study, it is a measured volume of water needed to make slurry from dry fine tailings. The average pore volume obtained for each column was about $600 \mathrm{ml}$ and as such twelve collections of $50 \mathrm{ml}$ volumes made up one pore volume. The collections are reported as pore volume numbers which are fractions of $600 \mathrm{ml}$, for example, the first collection is $50 \mathrm{ml} / 600$ $\mathrm{ml}=0.0833$; the second is $100 \mathrm{ml} / 600 \mathrm{ml}=0.167$ and so on. Leaching was done at $\mathrm{pH} 3$ and $\mathrm{pH}$ 7. $\mathrm{pH} 3$ (obtained by acidification with sulphuric acid) was aimed at simulating the acidity of a plume leaching through tailings profiles whereas $\mathrm{pH} 7$ simulated the $\mathrm{pH}$ of the water used in the spray jet technique (monitoring method) for creating a slurry of tailings during reprocessing. The columns were set up in duplicate such that T1 and T2 were used for leaching with the $\mathrm{pH} 7$ solution while D1 and D2 were used for leaching with the $\mathrm{pH} 3$ solution.

Samples were also obtained from an active slimes TSF that had just been decommissioned (sketch will be referred to later). An active slimes dam or TSF is one in which deposition, in the form of slurry, of tailings from a gold processing plant is occurring. When deposition of tailings is discontinued, usually after some years of operation, the slimes dam is said to be dormant. It is at this stage that reprocessing or remediation plans can be considered. Most of the processing on the Central Rand goldfield is of old dumps and is termed reprocessing as it is a way to salvage economically extractable gold in them. Sampling was done along the catena (at depths of $40-50 \mathrm{~cm}$ ) from the edge of the TSF towards the central pond. The measurement of $\mathrm{pH}$ of the tailings material was done by inserting a probe into a 1:1 wt. ratio of solid:deionised water.

Pure sulphate salts were used as proxies for the commonly found salts in efflorescent crusts that usually occur in the mining area. These were dissolved in a solid:liquid ratio of $1 \mathrm{~g}: 100$ $\mathrm{mL}$ in deionised water and paramaters such as $\mathrm{pH}$ and electrical conductivity (EC) assessed after stabilization.

Total analysis of elements in dried tailings material was conducted following digestion in a microwave system (Anton Paar, Switzerland). The digestion was carried out using hydrofluoric acid and aqua regia (a 3:1 mixture of hydrochloric acid and nitric acid). Elemental concentrations were determined by inductively coupled plasma spectroscopy (Spectro Genesis, Kleve, Germany).

Measurement of $\mathrm{pH}$ and EC was carried out with a portable kit (Multi Line F/Set 3, WTW, Germany), equipped with a $\mathrm{pH}$ electrode, an integrated temperature probe (SenTix 41), a standard conductivity cell (Tetra Con 375), and an oxidation-reduction potential probe (SenTix ORP). All reagents used were of analytical grade and certified reference materials were used for quality control. 


\subsection{Results and discussion}

\subsubsection{Leaching experiments}

During sampling, a $\mathrm{pH}$ of 7.8 was recorded for the tailings. This slightly elevated $\mathrm{pH}$ in the slimes is attributed to the addition of lime during gold extraction. This is done to keep the cyanide in solution as it escapes at low pH posing a toxicity problem (Funke, 1990). The results for elemental concentrations in tailings following total digestion in the microwave are presented in Table 1 . The results point to tailings as potential sources of leachable metals to the environment.

\begin{tabular}{cccccccccccccc}
\hline Element & $\mathbf{M g}$ & $\mathbf{N a}$ & $\mathbf{C a}$ & $\mathbf{K}$ & $\begin{array}{c}\mathbf{A l} \\
\mathrm{mg} \mathrm{kg}^{-1}\end{array}$ & $\begin{array}{c}\mathbf{F e} \\
\mathbf{C o}\end{array}$ & $\mathbf{N i}$ & $\mathbf{U}$ & $\mathbf{Z n}$ & $\mathbf{P b}$ & $\mathbf{C u}$ & $\mathbf{A s}$ \\
\hline & 1500 & 700 & 1600 & 8000 & 15000 & 16000 & 15 & 20 & 35 & 40 & 35 & 30 & 25 \\
\hline
\end{tabular}

Table 1. Average concentrations $\left(\mathrm{mg} \mathrm{kg}^{-1}\right)$ of selected elements in a composite sample from the TSF.

The results for leaching at $\mathrm{pH} 7$ (Fig. 3a) showed an initial increase in $\mathrm{pH}$ to about 8 (roughly the $\mathrm{pH}$ of the tailings) and then a drop. This could be attributed to the effects of buffering by the tailings material. This effect was also apparent when $\mathrm{pH} 3$ (Fig. 3b) was used for leaching. The leachates gave an initial $\mathrm{pH}$ above 4.5 which dropped gradually to 3 as leaching progressed up to two pore volumes. This trend of decreasing $\mathrm{pH}$ is likely to occur beyond two pore volumes.

(a)

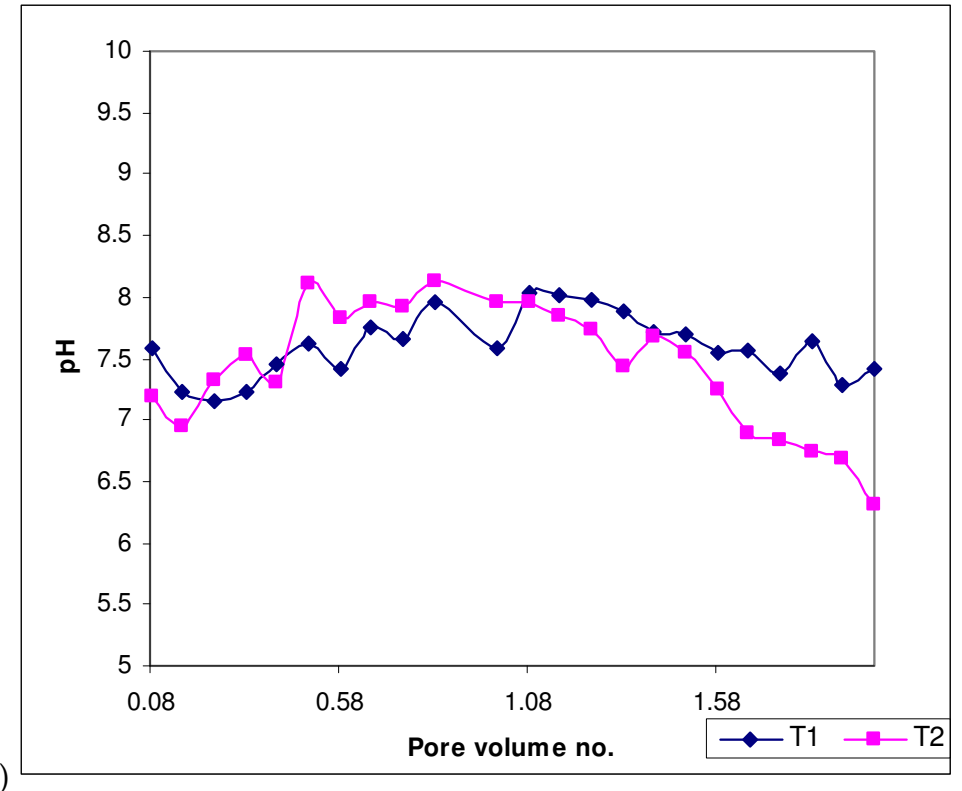




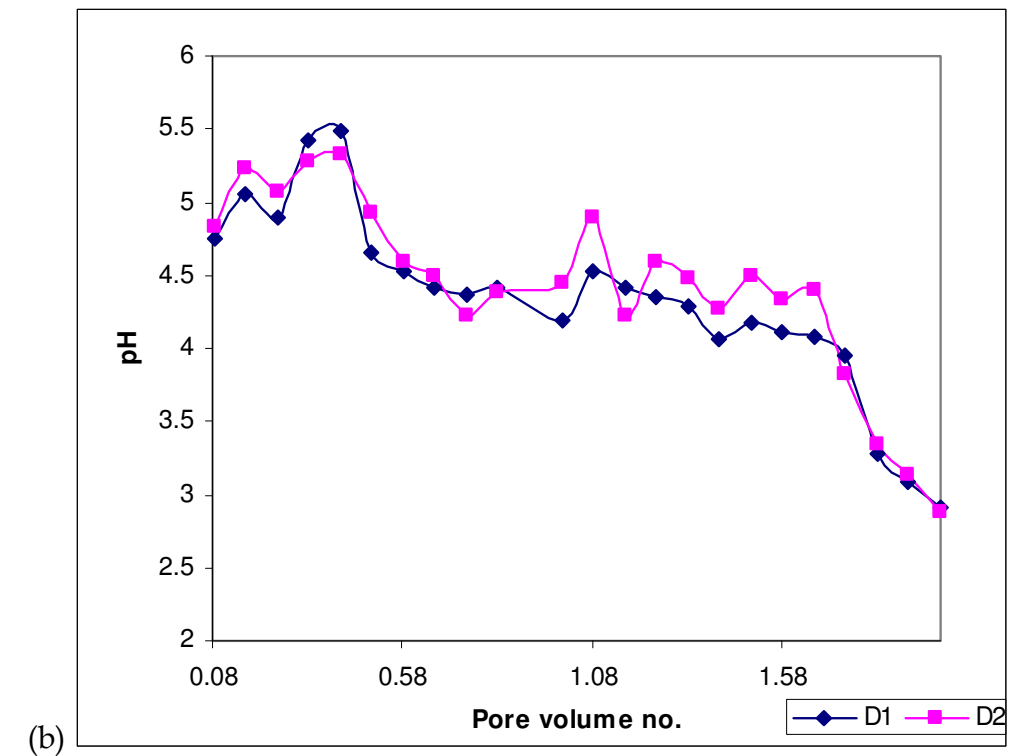

Fig. 3. $\mathrm{pH}$ versus leachate volume number for (a) $\mathrm{pH} 7$ in columns $\mathrm{T} 1$ and $\mathrm{T} 2$ and (b) $\mathrm{pH} 3$ in columns D1 and D2.

A plot of conductivity and $\mathrm{pH}$ versus the leachate volume number (Fig. 4) was done for $\mathrm{pH}$ 3. The results gave a correlation between the two parameters as expected, that is, the conductivity increased with a decrease in $\mathrm{pH}$.

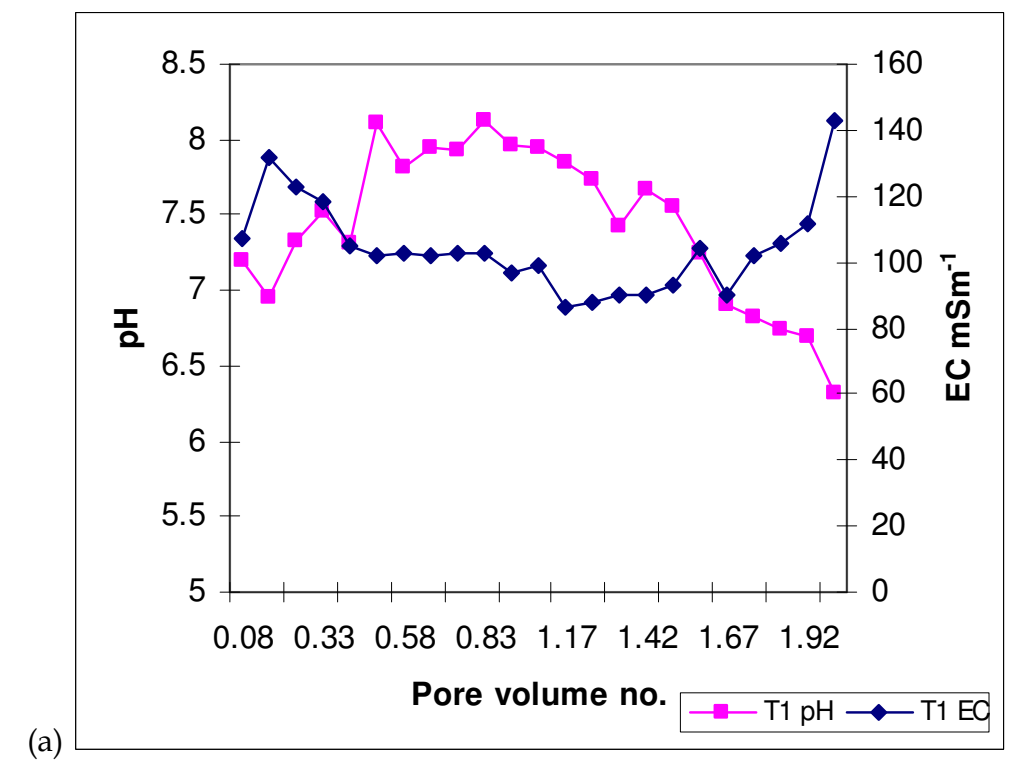




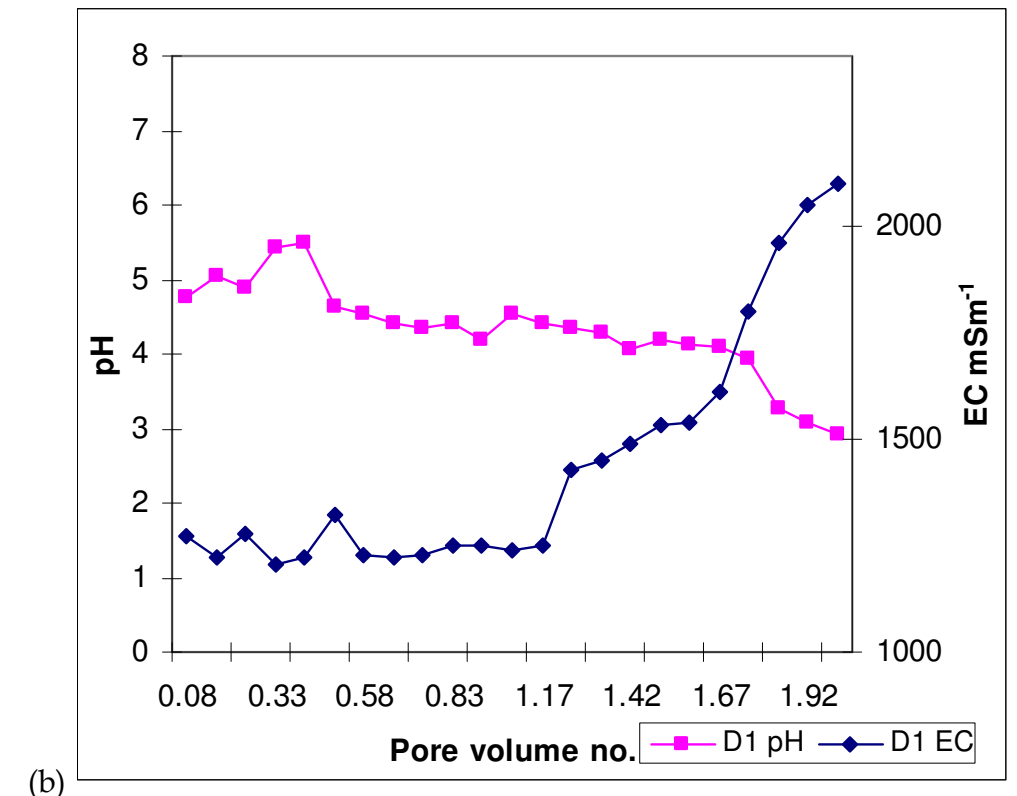

Fig. 4. $\mathrm{pH}$ and conductivity (EC) versus leachate volume number for (a) $\mathrm{pH} 7$ in column T1 and (b) pH 3 in column D1.

The effect of $\mathrm{pH}$ on the leachability of metals is shown in Fig. 5.

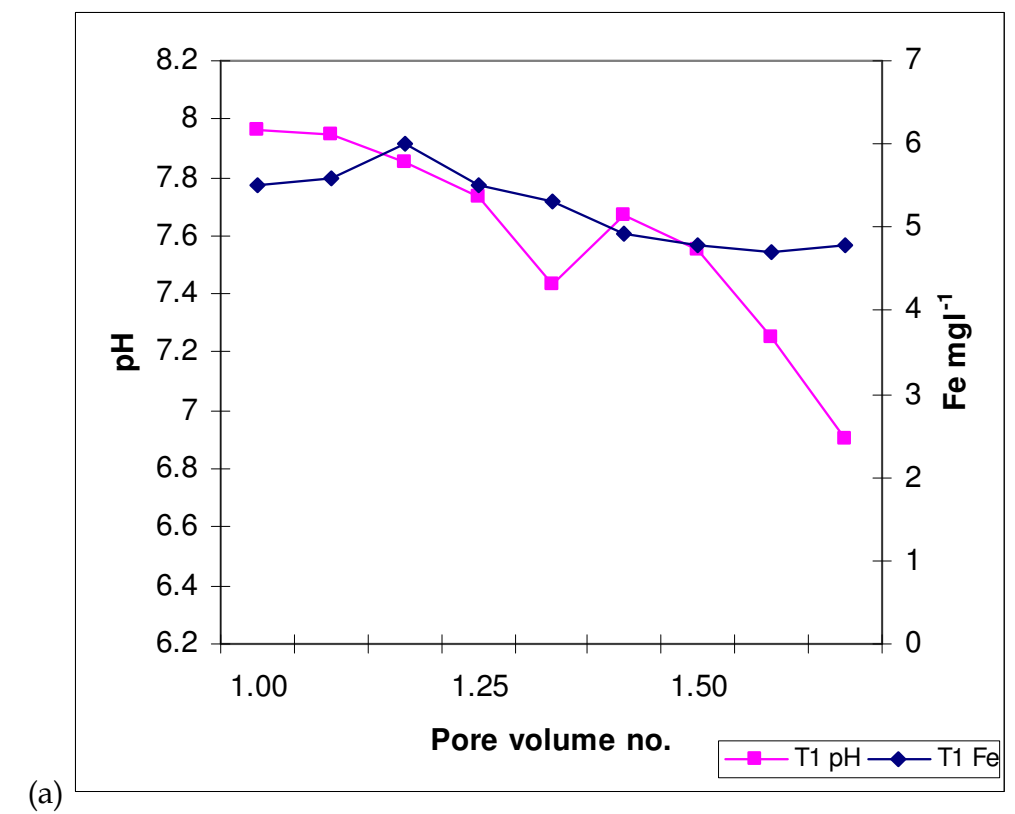


(b)
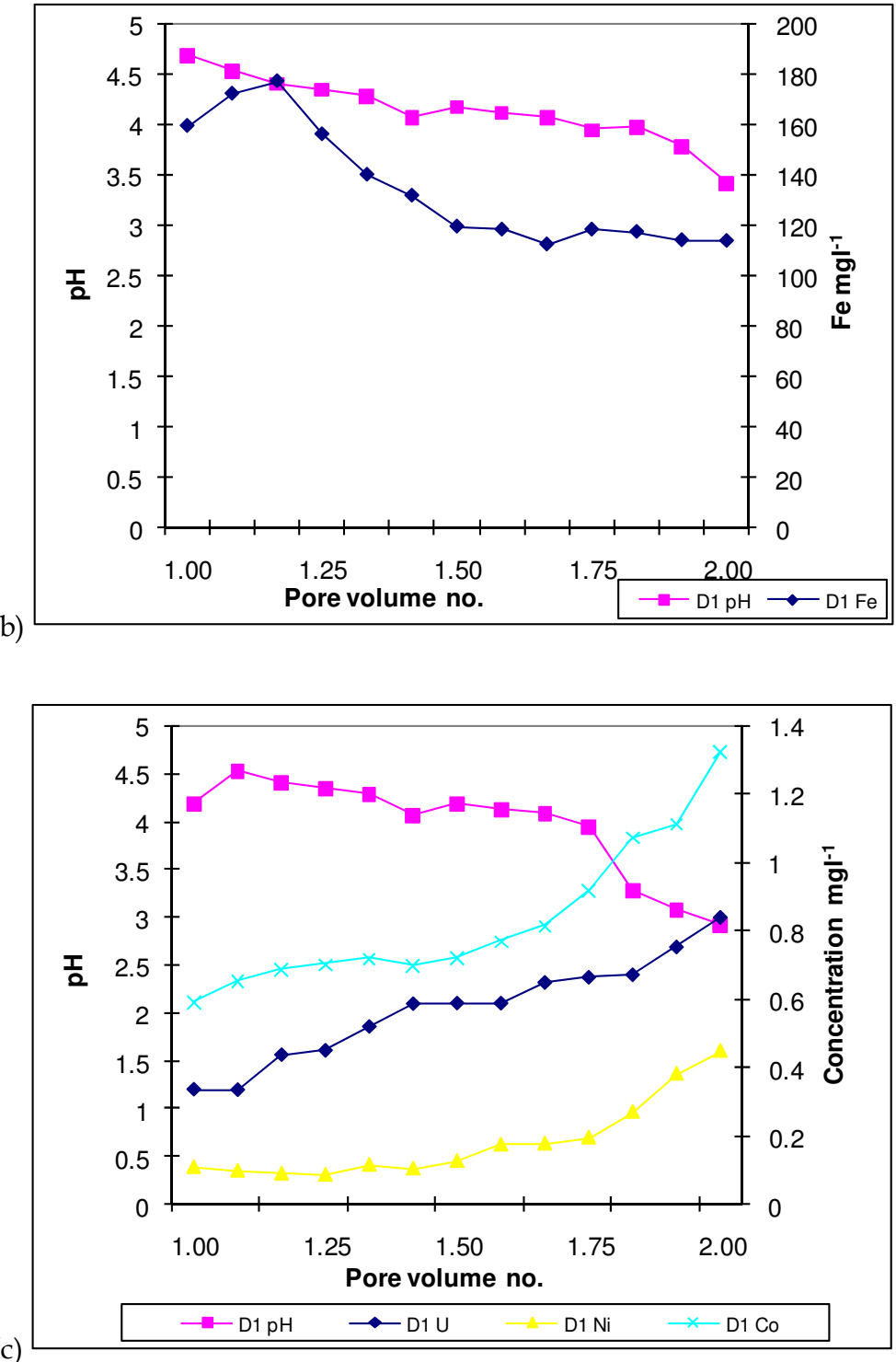

Fig. 5. $\mathrm{pH}$ and iron versus leachate volume number for (a) $\mathrm{pH} 7$ and (b) $\mathrm{pH} 3$; (c) pH, Co, U and $\mathrm{Ni}$ concentrations versus leachate volume number for $\mathrm{pH} 3$.

The metal concentrations increase with a drop in $\mathrm{pH}$. This is expected as the host ore in the material (sulphides) undergoes oxidation and releases the constituent metals. The iron concentrations, however, initially increased and then dropped (Fig. 5a and 5b). This drop could be attributed to the formation of hydrous ferric oxides. Once released, iron hydrolyses when it comes into contact with water (reactions 2 and 3 above). The resulting iron 
hydroxides have a low solubility and at a $\mathrm{pH}>3$ are quite stable in terms of reverse hydrolysis (Schwertmann, 1985). The low iron concentrations could be the reason for the non-balance, in terms of mass balance, between sulphates and iron (deriving from the oxidation of pyrite). However, no effect of co-precipitation was observed as the other metals had increasing concentrations in subsequent leachates. Further investigations would be required to assess this unusual phenomenon.

\subsubsection{Water quality}

The best representation of the water quality distribution in and around the gold mining areas in the East and Central Rand goldfields was given by Davidson (2003), Mphephu (2004) and Tutu et al. (2008). This work does not intend to re-invent the wheel in this regard, but rather to draw focus on some of the important contributing factors to variability in water chemistry in these areas as a result of interactions occurring in the tailings.

Firstly, tailings consist of a complex and dynamic heterogeneous physical-chemical matrix in which there are mineral $\leftrightarrow$ water interactions. These interactions can lead to the dissolution of some minerals into the water column while precipitation and adsorption can lead to the formation of new minerals (Allen et al., 1993). This, in part, explains the leaching behaviour of the metals discussed above. It was observed that prolonged leaching of neutral to basic tailings eventually leads to acid generation, and consequently a release of most elements constituting the host ores. This is illustrated in Fig. 6. Over time, the outer layer of the tailings gets oxidised and forms an oxidation layer with an oxidation front defining the boundary with the unoxidised layer. The plume emerging from this is expected to be a result of the interaction between the acidic fluid exiting the oxidised zone and the host ore (and buffering constituents) of the unoxidised zone.

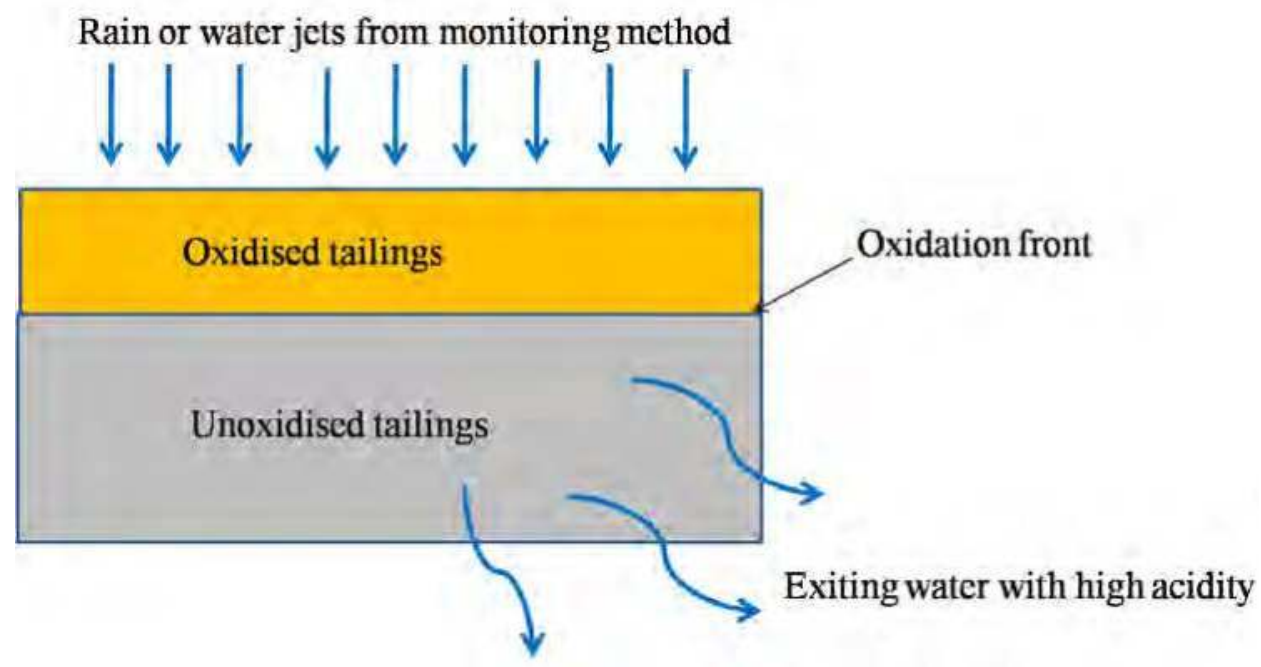

Fig. 6. A section through a TSF showing expected leaching outcomes for an AMD case. 
An acidic plume will be expected to exit if the generated acidity in the oxidised zone exceeds the buffering capacity in both the oxidised and unoxidised zones $\left(m_{\mathrm{H}^{+}}>m_{\mathrm{HCO}^{3}}\right)^{-}$. AMD depletes this buffering ability completely below a $\mathrm{pH}$ of about 4.2 by neutralizing carbonate and bicarbonate ions to form carbonic acid $\left(\mathrm{H}_{2} \mathrm{CO}_{3}\right)$. This is depicted by the following chemical equations:

$$
\begin{gathered}
\mathrm{H}^{+}+\mathrm{CO}_{3}^{2-} \rightarrow \mathrm{HCO}_{3}^{-} \\
\mathrm{H}^{+}+\mathrm{HCO}_{3}^{-} \rightarrow \mathrm{H}_{2} \mathrm{CO}_{3}
\end{gathered}
$$

The carbonic acid is unstable and readily breaks down into water and carbon dioxide:

$$
\mathrm{H}_{2} \mathrm{CO}_{3} \rightarrow \mathrm{H}_{2} \mathrm{O}+\mathrm{CO}_{2}
$$

However, acidic water exiting may contain some cyanide species (typically strong-acid dissociable cyanide complexes) despite the acidic regime, resulting in a concomitant mixture of high-sulphate, high-metal and moderately high-cyanide water (Bakatula et al., 2008). The TSF itself usually consists of varying physical-chemical parameters within it. This is illustrated better in the case of a decommissioned active slimes dam (Fig. 7).

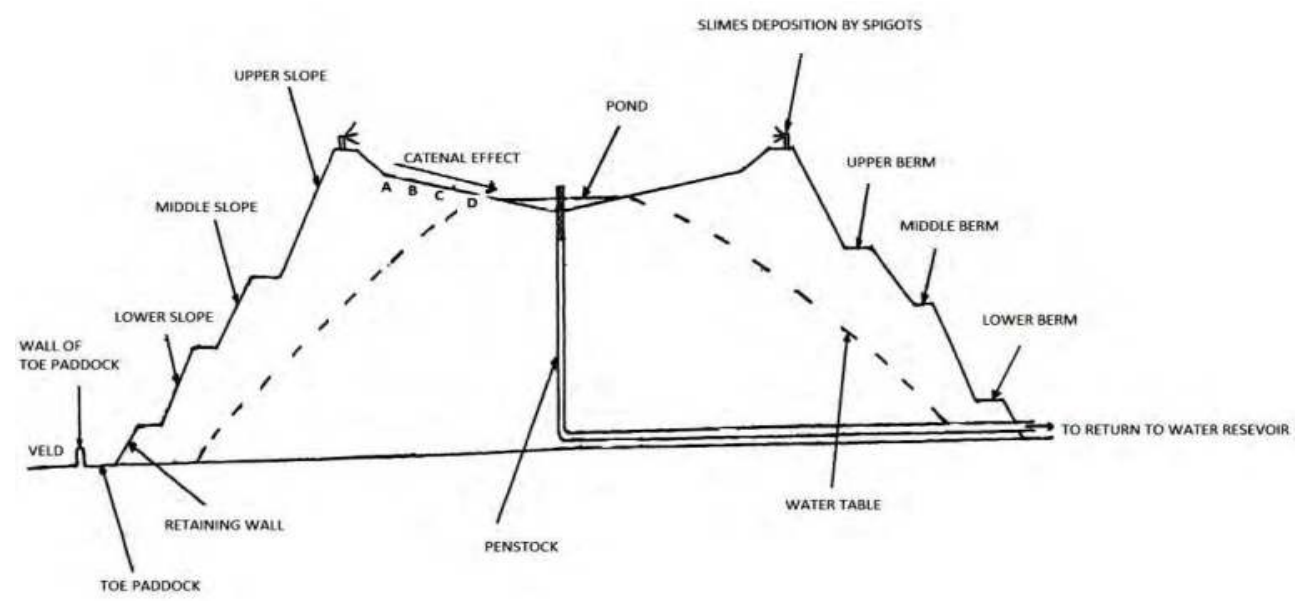

Fig. 7. General section of a TSF.

During operation, the material was discharged at the spigots from where it would spread out along the catena with coarse particles settling out first and the fines settling yonder, with some settling in the pond together with the water (Tutu, 2006). The material was basic at discharge (with $\mathrm{pH}$ values more than 9.5) as it was fresh from the processing plant where liming had been done.

The results for $\mathrm{pH}$ measurements on the TSF are presented in Table 2. 


\begin{tabular}{ccc}
\hline Level & Site & $\mathbf{p H}$ \\
\hline Top & (A) $30 \mathrm{~m}$ in & 7.60 \\
Top & (B) $80 \mathrm{~m} \mathrm{in}$ & 7.87 \\
Top & (C) $130 \mathrm{~m}$ in & 7.95 \\
Top & (D) $180 \mathrm{~m}$ in & 8.63 \\
Berm & Upper berm & 3.65 \\
Berm & Mid berm & 2.54 \\
Berm & Lower berm & 2.70 \\
Top & Pond & 4.01 \\
\hline
\end{tabular}

Table 2. $\mathrm{pH}$ measurements for selected areas within TSF.

The berms displayed low $\mathrm{pH}$ values. This could be attributed to their constituent coarse material being more susceptible to oxygen entrainment, thus oxidising quickly and releasing acidity. In some cases, such as in TSFs with vegetated slopes, the lower berms may have a neutral to basic $\mathrm{pH}$ and higher contents of organic matter due to accumulation of eroded material and debris. Along the catena, the $\mathrm{pH}$ is increasingly basic due to the basic slurry flowing down as well as the slow oxidation of the finer materials in that area. However, the pond water is acidic largely due to the fast oxidation of residual sulphides in the aqueous solution and surface flow from the acidic zones on the TSF edges (Tutu, 2006).

The results for metal concentrations along the catena are presented in Fig. 8.

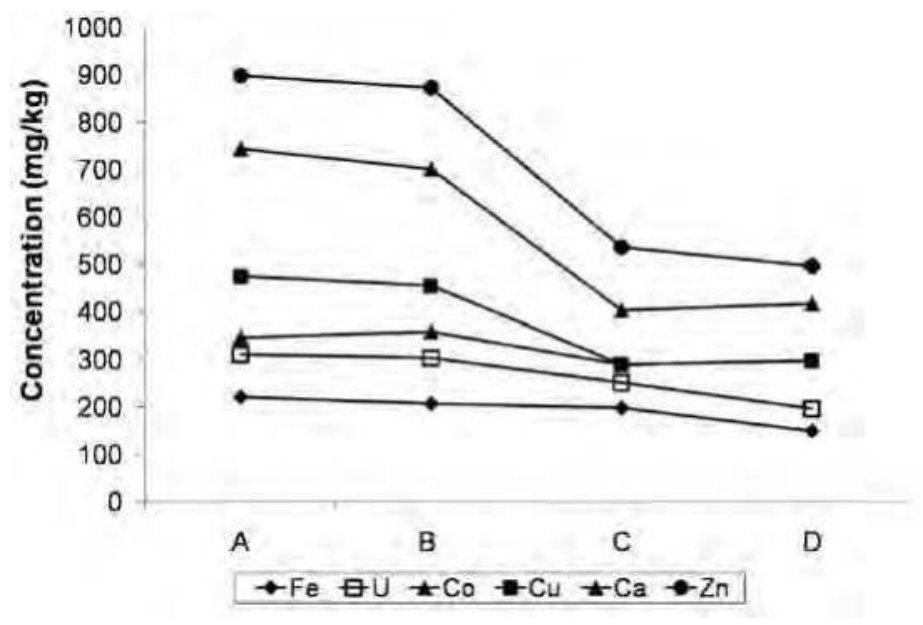

Fig. 8. Metal concentrations across the TSF catena from the edge (A) towards the central pond (D).

The metal concentrations decrease along the catena and this could be due to precipitation as the solid material is separated from the aqueous phase during material flow. The elevated 
$\mathrm{pH}$ of the slimes is above $\mathrm{pH}$ of hydrolysis of most of the metals. It should be noted that metal concentrations down the catena could also be determined by density segregation as the material settles, with heavier metals settling in coarser material near the edge and the lighter ones in finer material towards the pond (Tutu, 2006).

Secondly, in some cases where tailings footprints have been rehabilitated by liming, the alkalinity of the exiting water plume may exceed acidity, resulting in neutral to basic water. It is common practice in the Central Rand goldfield to plough the footprints followed by levelling of the surface and then application of lime to eradicate residual acidity in the soil. However, the water leaching through these facilities may still contain elevated concentrations of some elements (e.g. $\mathrm{Ca}, \mathrm{Mg}, \mathrm{U}, \mathrm{As}, \mathrm{Cr}, \mathrm{V}$ ) and sulphates in addition to cyanide species. Elements such as $\mathrm{U}, \mathrm{As}, \mathrm{Cr}$, and $\mathrm{V}$ tend to form soluble carbonate complexes (Levinson, 1974; Langmuir, 1997; Zielinski et al., 1997; Tutu, 2006).

Thirdly, there can be added variability in water chemistry and quality as a result of efflorescent crusts. These salt crusts occur as a result of evaporation of shallow groundwater. They contain a variety of sulphate-based salts and fingerprint the local geochemistry of where they are found. The most common among the salts found in the Central Rand goldfield are: gypsum $\left(\mathrm{CaSO}_{4} \cdot 2 \mathrm{H}_{2} \mathrm{O}\right)$, jarosite $\left(\mathrm{KFe}\left(\mathrm{SO}_{4}\right)_{2}(\mathrm{OH})_{6}\right)$, melanterite $\left(\mathrm{FeSO}_{4} \cdot 7 \mathrm{H}_{2} \mathrm{O}\right)$, copiapite $\left((\mathrm{Fe}, \mathrm{Mg}) \mathrm{Fe}_{4}\left(\mathrm{SO}_{4}\right)_{6}(\mathrm{OH})_{2} \cdot 20 \mathrm{H}_{2} \mathrm{O}\right)$, goslarite $\left(\mathrm{ZnSO}_{4} \cdot 7 \mathrm{H}_{2} \mathrm{O}\right)$, epsomite $\left(\mathrm{MgSO}_{4} .7 \mathrm{H}_{2} \mathrm{O}\right)$ (Naicker et al., 2003; Tutu et al., 2008). They occur on the tailings, next to tailings ponds, along stream banks and on tailings footprints (Fig. 9). In some instances, particularly where a $\mathrm{pH}$ gradient or another factor such as incongruent precipitation is prevalent, conspicuous segregation of different salts occurs. Bands of brownish (Fecontaining), pinkish (Co and Mn-containing), bluish (Cu-containing), whitish (Ca and $\mathrm{Mg}$ containing) salts could be seen. These salts contain elevated concentrations of metals, metalloids, sulphates (Rosner et al., 2001; Rosner \& van Schalkwyk, 2000; Naicker et al., 2003; Tutu et al., 2008) and cyanide species (Bakatula et al., 2008).

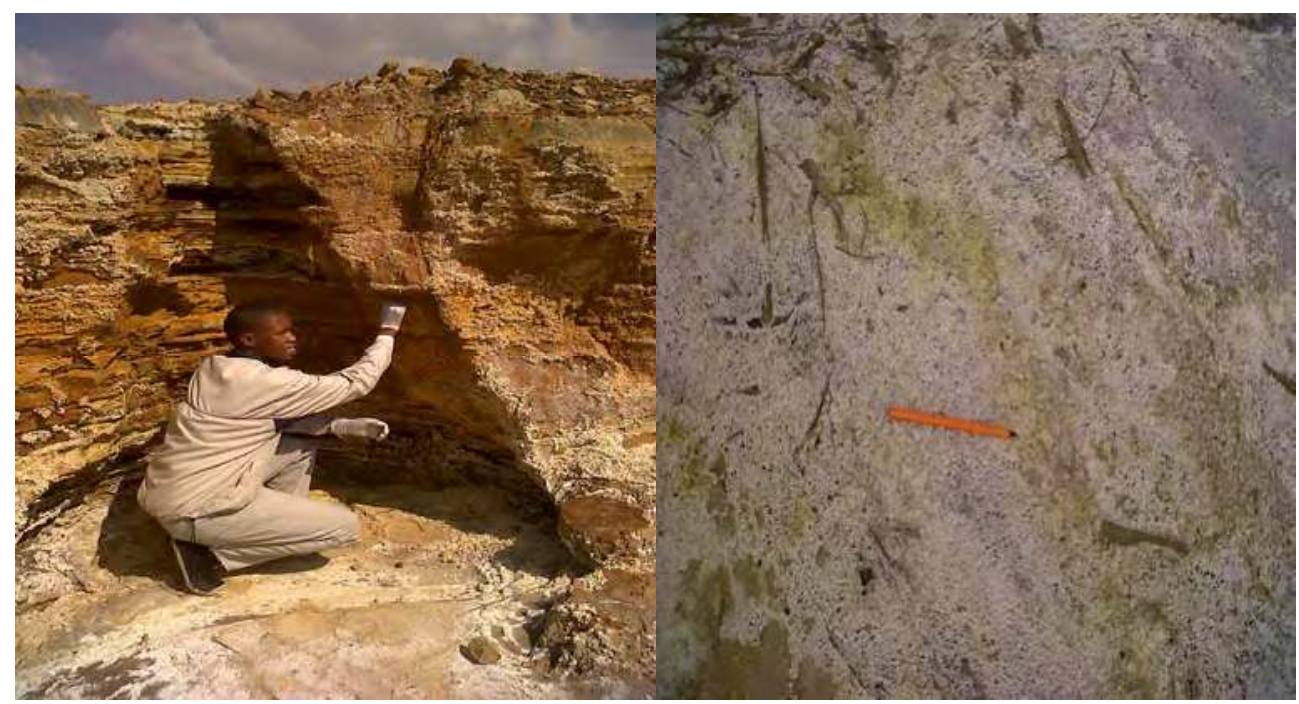




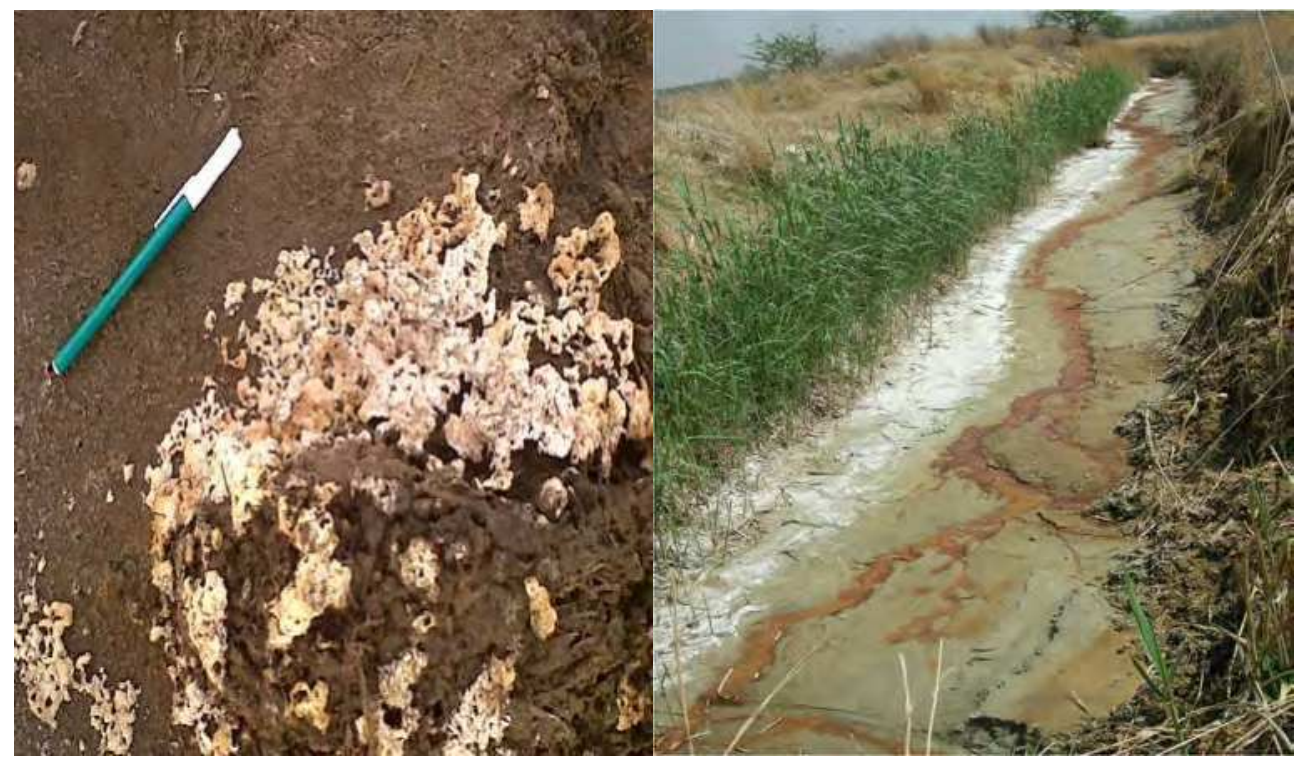

Fig. 9. Efflorescent crusts (from the top left in a clockwise direction): at a tailings footprint precipitates on the wall and base (floor); distinct white and yellowish precipitates along a flow path from the footprint; pinkish lumps of precipitates; and precipitates along a stream draining from a TSF (distinct Fe precipitates along the stream can be seen).

The contribution of individual salts to receiving water chemistry during dissolution is presented in Fig. 10 using the pure salt forms. In this case, the dissolution was done in de-

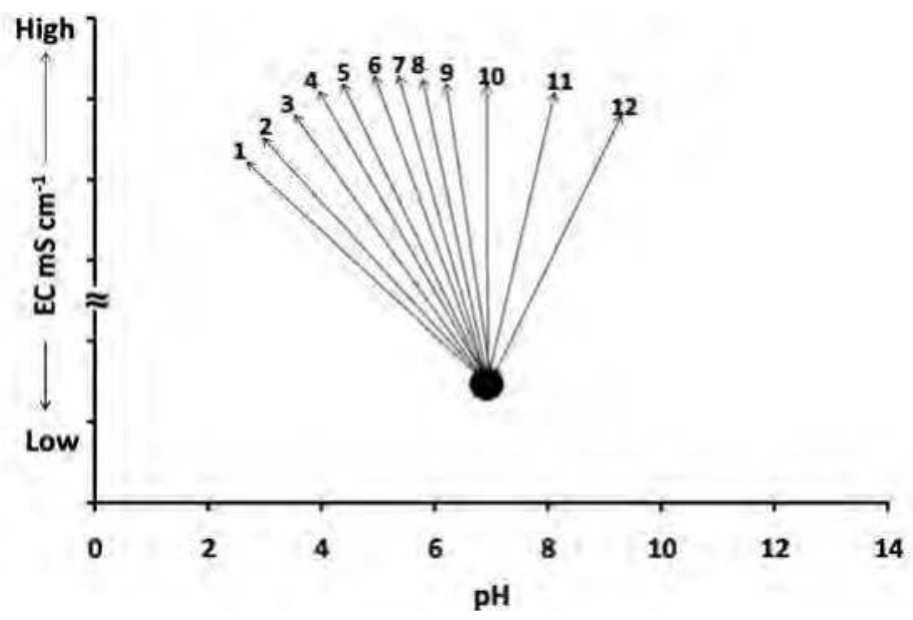

Fig. 10. Geochemical vectors showing expected changes in $\mathrm{pH}$ and $\mathrm{EC}$ of receiving water on dissolution of: (1) $\mathrm{Cr}\left(\mathrm{SO}_{4}\right)_{3} .15 \mathrm{H}_{2} \mathrm{O}$; (2) $\mathrm{CuSO}_{4} .5 \mathrm{H}_{2} \mathrm{O}$; (3) $\mathrm{FeSO}_{4}$; (4) $\mathrm{Al}_{2}\left(\mathrm{SO}_{4}\right)_{3} .16 \mathrm{H}_{2} \mathrm{O}$; (5) $\mathrm{NiSO}_{4} \cdot 6 \mathrm{H}_{2} \mathrm{O}$; (6) $\mathrm{ZnSO}_{4} \cdot 7 \mathrm{H}_{2} \mathrm{O}$; (7) $\left(\mathrm{NH}_{4}\right)_{2} \mathrm{SO}_{4} ;(8) \mathrm{MgSO}_{4} ;$ (9) $\mathrm{Na}_{2} \mathrm{SO}_{4} ;(10) \mathrm{MnSO}_{4} \cdot \mathrm{H}_{2} \mathrm{O}$; (11) $\mathrm{CaSO}_{4} \cdot 2 \mathrm{H}_{2} \mathrm{O} ;(12) \mathrm{K}_{2} \mathrm{SO}_{4}$. 
ionised water $\left(\mathrm{EC}=0.018 \mathrm{mS} \mathrm{cm}^{-1}\right.$ and $\left.\mathrm{pH}=7\right)$, represented by the central dot. The arrows show the direction of $\mathrm{pH}$ change and in all cases an increase in EC as the dissolution of the salts increases the ion concentrations.

Practically, the crusts are a mixture of the various salts and thus the resultant effect would be their combined effect, with the dominating salt in aqueous solution determining the overall effect on $\mathrm{pH}$. It should be noted that by virtue of containing a mixture of minerals, the salts would likely undergo incongruent dissolution in water. Congruent dissolution occurs when all products are soluble, for example, the dissolution of pure gypsum. Incongruent dissolution is likely to contribute to episodic release of the respective elements in the salts as well as the distinct separation of the minerals when the salts re-precipitate.

\section{Case study 2: Water quality at a decommissioned opencast coal operation in Mpumalanga Province, South Africa}

Coal mining in South Africa is maturing and there are many decommissioning collieries in the major coalfields (Pinetown et al., 2007; Prevost, 2004). AMD is a major problem at several mines in the Witbank Coalfields in the Mpumalanga Province. In some cases, AMD has been found to originate from opencast workings which had been backfilled and has found its way to surrounding natural water courses (Geldenhuis, 1998). The effect of AMD from coal mines has led to serious ecological consequences and mining next to rivers puts the South African supply of fresh water at risk (McCarthy, 2008).

In this work, the behaviour of backfill spoil material in a decommissioned opencast coal mine was assessed with respect to acid-generating potential. The facility was partly rehabilitated by applying a top soil cover to the spoil material and vegetating with some grass. Once a year, lime is applied over the facility at a dosage of $700 \mathrm{~kg}$ per hectare as a control for acidity.

The quality of water exiting the facility was also assessed. The protocols followed are explained briefly in the following section and the results presented later.

\subsection{Sampling and analytical protocol}

The samples were collected from a decommissioned opencast mine operation (Fig. 11). For solids, top soils (labeled 1 e.g. A1) were collected at $40 \mathrm{~cm}$ depths while subsoils (labeled 2 e.g. A2) were collected at $1.5 \mathrm{~m}$ depths. The soils were collected into polypropylene containers. Both surface and groundwater (borehole water) samples were collected according to commonly accepted sampling protocols (Hermond and Fechner-Levy, 2000).

The solid samples were dried in an oven at $40^{\circ} \mathrm{C}$ and then pulverized. Total elemental concentrations were determined following microwave digestion (as in Case 1). Assessment of acid generation potential was conducted using the acid base accounting (ABA) technique.

Acid base accounting is a method that is widely used to evaluate the characteristics and behaviour of mineral ores in an effort to assess the potential of AMD generation (Usher et al., 2003). It provides values that help in assessing the acid-producing and acid-neutralising potential of sulphidic material (Skousen et al., 2002). It is applied to opencast coal mine spoil material and to predict the post-mining water quality at polluted sites (Skousen et al., 2002). The soil samples gathered at the site will allow for the estimation of the total overburden amounts. The recommended test procedures for ABA are as follows (Usher et al., 2003): 
- $\quad$ Initial $\mathrm{pH}$

- $\quad$ Final $\mathrm{pH}$

- Acid potential (AP)

- Neutralisation potential (NP) and

- $\quad$ Net neutralisation potential (NNP)

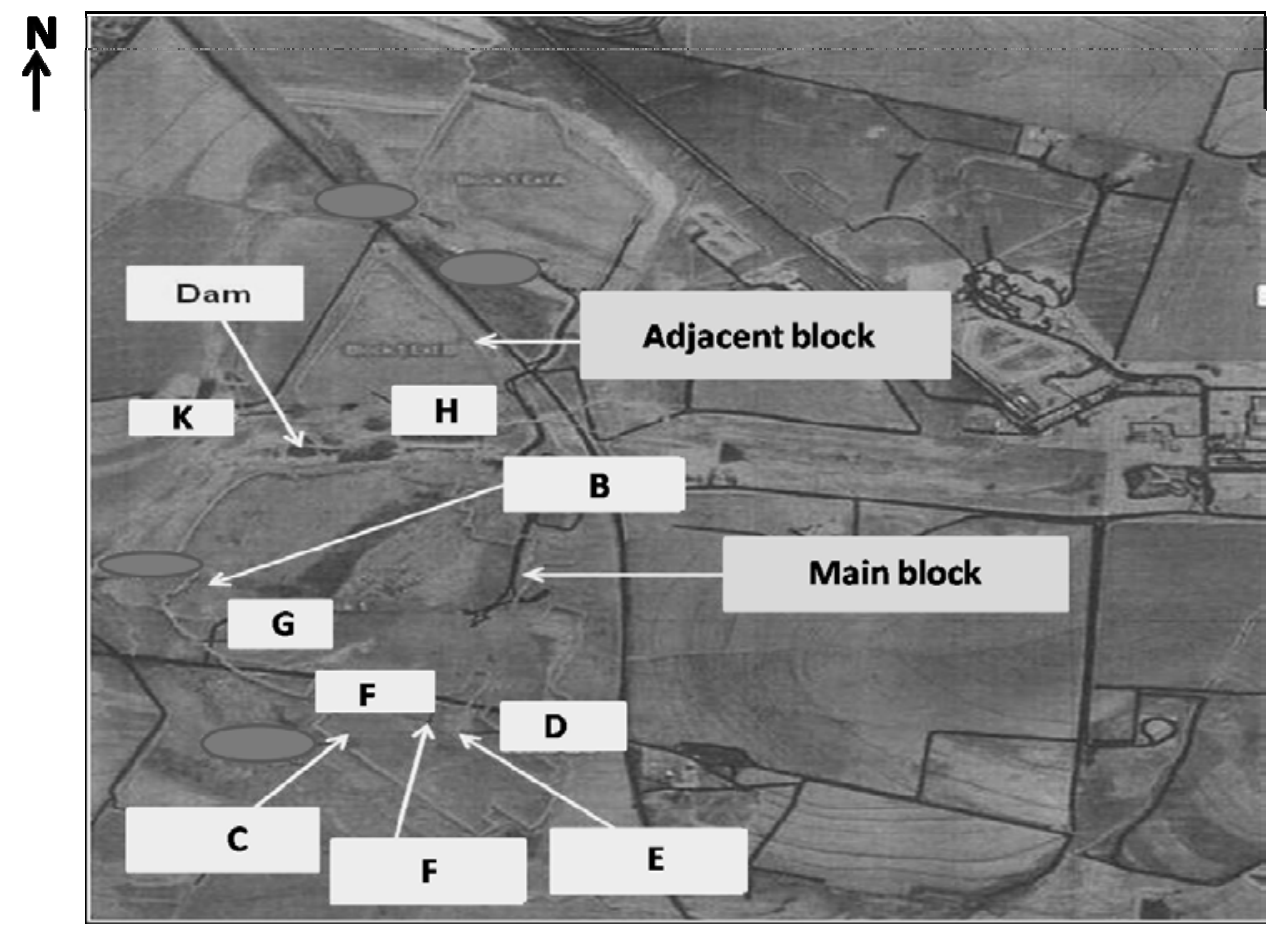

Fig. 11. Sketch of location of sampling points at the decommissioned opencast operation.

The initial $\mathrm{pH}$ is a measurement of the $\mathrm{pH}$ of the spoil material before oxidation. The recommended ratio of sample to deionised water is $1 \mathrm{~g}: 10 \mathrm{~mL}$, and the $\mathrm{pH}$ is measured after 24 hours. This recommendation allows for a more complete solubility reaction and a more realistic determination of the initial $\mathrm{pH}$ (Usher et al., 2003). The final $\mathrm{pH}$ is a measure of the $\mathrm{pH}$ of the spoil material after it has been completely oxidised. The NP is a measure of the amount of acid-neutralising compounds in the coal samples and overburden. It mostly measures carbonates and alkaline earth cations. The NP is calculated from the amount of acid neutralised by $\mathrm{CaCO}_{3}$ in the sample. The AP is the maximum amount of sulphuric acid that can be produced from the oxidation of sulphur-containing minerals in the rocks or overburden material (Usher et al., 2003).

After the NP and AP are calculated, the total NNP is determined by subtracting the AP from the NP i.e. NPP = NP - AP. The NNP values are separated into categories which indicate 
either the acidity or alkalinity of the spoil material (Skousen et al., 2002). Conceptually, a sample with NNP $<0$ is potentially acid-generating and a sample with NNP $>0$ indicates more acid-neutralising potential (Skousen et al., 2002).

Field parameters and elemental concentrations were determined as in Case 1 . Anions $\left(\mathrm{Cl}^{-}\right.$ and $\mathrm{SO}_{4}{ }^{2-}$ ) were determined by ion chromatography (Metrohm 761 Compact Ion Chromatograph, Switzerland) while carbonates were determined by titrimetry (Clesceri et al., 1998). Water classification was conducted using Statistica ver 8 (Statsoft, USA).

\subsection{Results and discussion}

\subsubsection{Analysis of solids}

The analytical results of the total metal concentration in the soil samples of the mining area are shown in Table 3.

\begin{tabular}{cccccccccccccc}
\hline Sample Description & $\mathrm{Fe}$ & $\mathrm{Mn}$ & $\mathrm{Ni}$ & $\mathrm{Ca}$ & $\mathrm{Mg}$ & $\mathrm{S}$ & $\mathrm{Pb}$ & $\mathrm{Cu}$ & $\mathrm{Al}$ & $\mathrm{Cd}$ & $\mathrm{Cr}$ \\
\hline & & & & & \multicolumn{1}{c}{$\mathrm{mg}^{-1}$} & & & & & \\
\hline A1 & Top soil & 43689 & 375 & 541 & 540 & 1262 & 502 & $\mathrm{nd}$ & 54 & 23689 & 75 & 416 \\
A2 & Sub soil & 48062 & 887 & 686 & 26841 & 18023 & 2616 & 2.91 & 48 & 21318 & 115 & 205 \\
B1 & Top soil & 10019 & 158 & 890 & 297 & 582 & 135 & 0.96 & 38 & 30058 & 90 & 1029 \\
B2 & Sub soil & 30517 & 295 & 842 & 14016 & 9543 & 604 & 1.99 & 49 & 26839 & 100 & 704 \\
C1 & Top soil & 49138 & 483 & 889 & 28927 & 17050 & 2395 & 4.79 & 60 & 25096 & 121 & 512 \\
C2 & Sub soil & 52908 & 453 & 775 & 7054 & 2097 & 2097 & 6.67 & 41 & 39085 & 119 & 251 \\
D1 & Top soil & 52970 & 394 & 474 & 2142 & 1266 & 636 & 1.95 & 55 & 36417 & 72 & 483 \\
D2 & Sub soil & 37880 & 227 & 801 & 499 & 1668 & 382 & 2.94 & 73 & 44063 & 116 & 565 \\
E1 & Top soil & 37512 & 443 & 711 & 22951 & 12825 & 1061 & 0.96 & 59 & 26615 & 96 & 444 \\
E2 & Sub soil & 53435 & 458 & 722 & 21851 & 13645 & 1145 & 4.77 & 48 & 24427 & 115 & 158 \\
F1 & Top soil & 52207 & 792 & 811 & 32438 & 18810 & 3167 & 1.92 & 67 & 23417 & 109 & 480 \\
F2 & Sub soil & 43288 & 323 & 406 & 936 & 1362 & 4767 & nd & 33 & 28988 & 76 & 131 \\
G1 & Top soil & 44197 & 379 & 766 & 314 & 907 & 89 & 0.97 & 54 & 44004 & 84 & 868 \\
G2 & Sub soil & 52069 & 532 & 745 & 28874 & 21655 & 1636 & 4.81 & 37 & 22137 & 118 & 135 \\
H1 & Top soil & 24584 & 306 & 1360 & 572 & 790 & 26 & 3.92 & 44 & 26836 & 142 & 784 \\
H2 & Sub soil & 75696 & 386 & 1011 & 648 & 1021 & 3554 & 0.96 & 66 & 21422 & 91 & 2402 \\
J1 & Top soil & 55632 & 1959 & 857 & 26053 & 1567 & 274 & 3.92 & 63 & 9794 & 114 & 549 \\
J2 & Sub soil & 77810 & 571 & 984 & 7143 & 2952 & 801 & 8.57 & 54 & 13905 & 116 & 952 \\
K1 & Top soil & 78257 & 598 & 829 & 4212 & 486 & 5268 & 5.88 & 80 & 23898 & 101 & 988 \\
K2 & Sub soil & 46223 & 599 & 1504 & 55268 & 32505 & 541 & 6.96 & 65 & 20676 & 165 & 1157 \\
\hline
\end{tabular}

Table 3. Total metal concentrations in soil samples collected at the decommissioned opencast mine. 
The results pointed to elevated concentrations of trace elements, particularly $\mathrm{Fe}, \mathrm{Mn}, \mathrm{Cd}, \mathrm{Cr}$. The concentration of Fe was notably high, exceeding $78000 \mathrm{mg} \mathrm{kg}^{-1}$ in sample K1. However, since this was a top soil sample, and its source not being the mining area, the source of Fe could not be ascertained. The sub-soils generally showed higher concentrations of sulphur compared to the top soils. A quick assessment of correlation revealed a strong correlation between iron and sulphur, an indication of the presence of pyrite $\left(\mathrm{FeS}_{2}\right)$ in the overburden material. However, there could be other Fe-sulphur compounds such as pyrrhotite $\left(\mathrm{Fe}_{1-\mathrm{x}} \mathrm{S}\right)$ and iron sulphate $\left(\mathrm{FeSO}_{4}\right)$.

The interaction between the top and sub-soil with respect to upward movement of pollutants e.g. due to capillary action was not ascertained in this study, but may not be ignored as the amount of evaporation exceeds precipitation in the study area. This is evidenced by the occurrence at certain spots of efflorescent salts similar to those described in Case 1. Other trace elements found include $\mathrm{Pb}$ and $\mathrm{Cu}$ which had concentrations of 8.57 and $80 \mathrm{mg} \mathrm{kg-1}$, respectively.

The results for initial and final $\mathrm{pH}$ of soil samples are presented in Fig. 12.

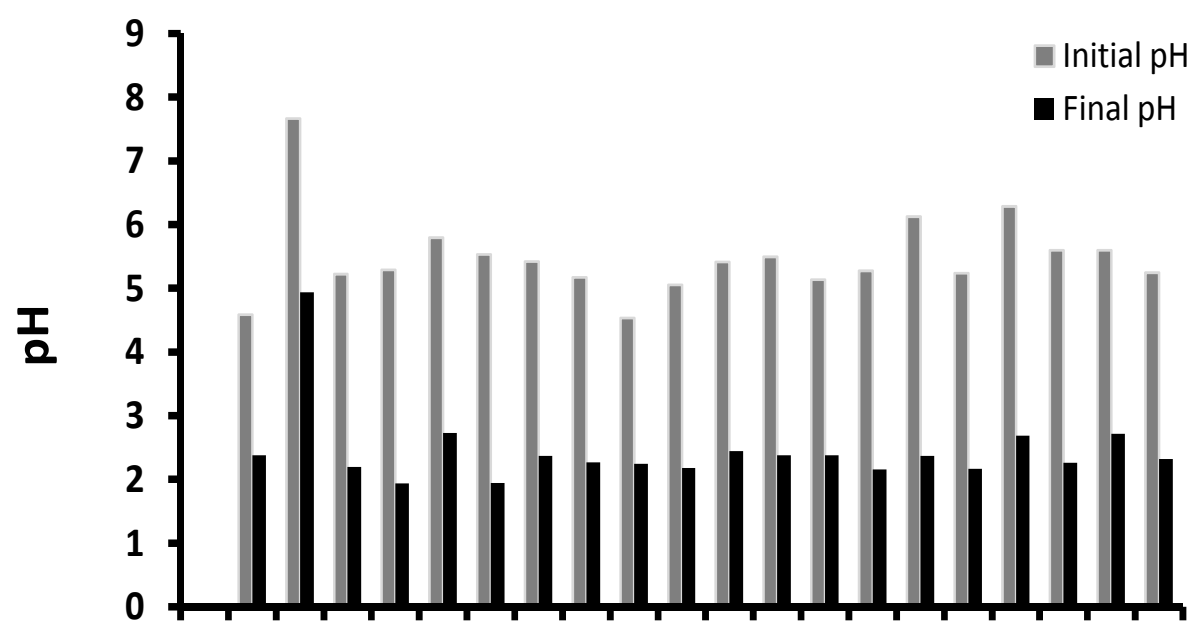

A1 A2 B1 B2 C1 C2 D1D2 E1 E2 F1 F2 G1G2 H1H2 J1 J2 K1 K2

Fig. 12. The initial and final $\mathrm{pH}$ of soil samples before and after complete pyrite oxidation.

The initial $\mathrm{pH}$ values were in the range 4.54 to 6.29 . As explained previously, the initial $\mathrm{pH}$ values indicate the immediate acidic or basic characteristic of the sample and it could also indicate if acid has already been generated. The results obtained point to acid generation as a result of the abundance of oxidisable pyrite in the area. An elevated initial $\mathrm{pH}$ of 7.66 was observed for sample A2 and this was attributed to the soil type that was a mixture of clay soil and ash. Coal ash is usually alkaline, but it is not clear how this came to be added to the 
spoil material at that point. The final $\mathrm{pH}$ of the samples showed that after complete oxidation, the $\mathrm{pH}$ of the soil would be less than 2.5 in most samples and acidic conditions would dominate. Sample B2 had a lower final $\mathrm{pH}$ of 1.94, suggesting that the total available carbonates could have already been neutralized or leached out leaving a lesser source of alkalinity to buffer the acid.

The results for NNP are presented in Fig. 13. Negative values of NNP were obtained for all samples in the area, with the lowest recorded value being $-9.8 \mathrm{~kg} \mathrm{t}^{-1} \mathrm{CaCO}_{3}$ for sample G2. The negative NNP values implied that the soil did not have enough $\mathrm{CaCO}_{3}$ to neutralise the acidity generated in the soil hence there was a potential of acidic drainage in the area.

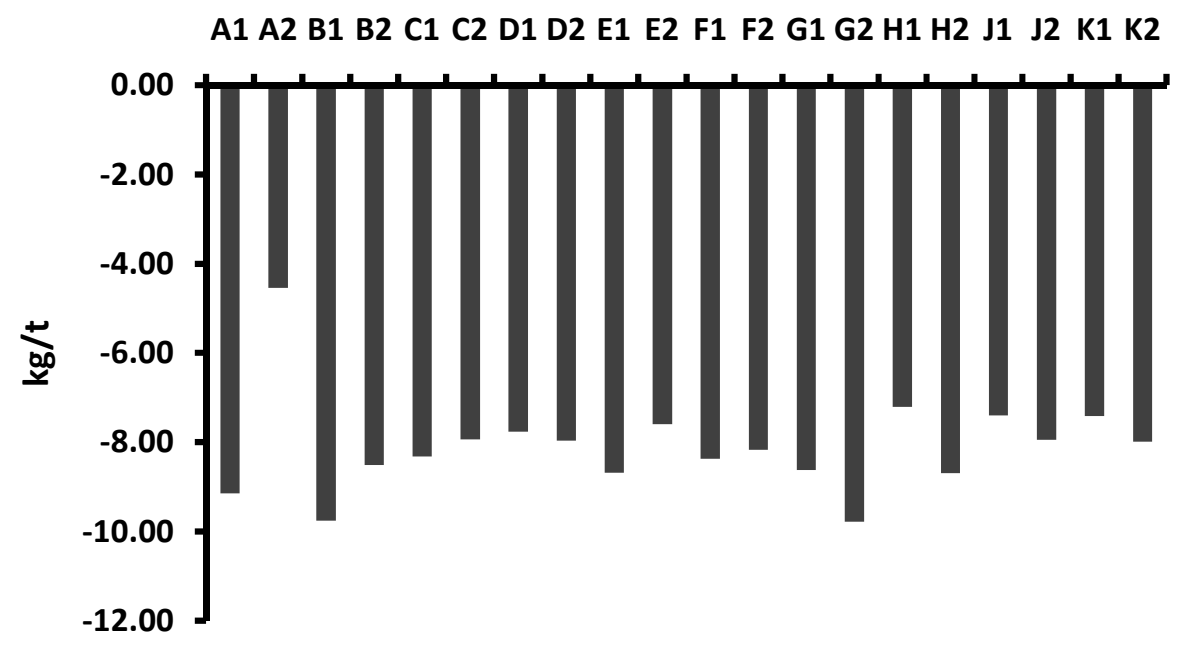

Fig. 13. Variation in the net neutralising potential (NNP) of soil samples.

\subsubsection{Water analysis}

The results for the water samples collected in the area are presented in Table 4 . The results for the $\mathrm{pH}$ measurements showed that the $\mathrm{pH}$ of the borehole and surface water in the area ranged from 5.92 to 9.00 . 


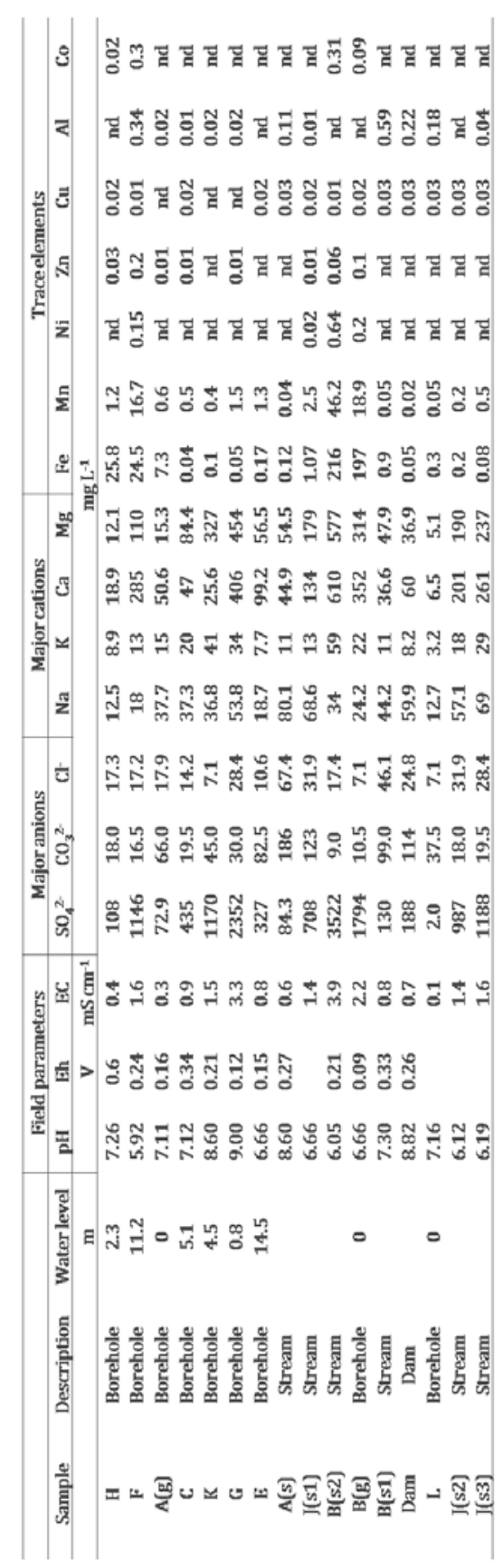

Table 4. Water analysis results for samples collected at the decommissioned opencast operation (nd - not detected; blank spaces are for parameters not analysed). 
Within the former mining area (Main block), the surface water showed mostly neutral to alkaline $\mathrm{pH}$ while the borehole water showed moderately acidic to neutral $\mathrm{pH}$. The $\mathrm{pH}$ variation showed that as the water flowed downward from the dam towards the decant point at $\mathrm{B}$, there was a decrease in $\mathrm{pH}$ from alkaline to moderately acidic. It was observed that some borehole water within the Main block had alkaline $\mathrm{pH}$ values of between 8 and 9. Examples are boreholes at $\mathrm{G}$ and $\mathrm{K}$. This was attributed to the depth of the borehole water from the surface. The lower the borehole water depth, the higher the $\mathrm{pH}$ because the borehole water was closer to the surface and its $\mathrm{pH}$ was increased by the presence of the lime that was applied on the top soil. The water depths of boreholes $\mathrm{G}$ and $\mathrm{K}$ were 0.8 $\mathrm{m}$ and $4.48 \mathrm{~m}$, respectively. These depth values were contrasted to the values for boreholes $\mathrm{E}$ and $\mathrm{F}$ which had water depths of $14.5 \mathrm{~m}$ and $11.22 \mathrm{~m}$ and $\mathrm{pH}$ values of 6.66 and 5.92, respectively. This discrepancy could be explained by the lag in the movement of groundwater. The water percolating as rain water dissolves the lime on the top soil thus an elevated $\mathrm{pH}$ for shallow groundwater. Some of this water flows as surface water to recharge surface water bodies. When the percolating water reaches the deeper zones, however, the buffering capacity is depleted as more and more pyrite in the spoil material is oxidized and acid generated. It would be expected that once the top soil lime is exhausted, even the shallow groundwater will tend to be acidic. Liming is conducted every January, but previous results of the $\mathrm{pH}$ of the borehole water show that towards the end of the year, the $\mathrm{pH}$ decreased as the added carbonates got exhausted. This acid generation corroborates the results obtained for NNP. The dam in the area recorded an alkaline $\mathrm{pH}$ of 8.82 . This would be expected as the dam is recharged mainly by surface flow and also dilution effects are important.

EC values were elevated in most of the cases, confirming what was noted previously about the possibility of having high dissolved ions despite the elevated $\mathrm{pH}$. For instance, sample B was a soil sample collected next to a decant point. At this point, a borehole where the groundwater was emerging at the surface and analytical results showed moderately acidic water ( $\mathrm{pH}$ 6.7), elevated concentration of the sulphates $\left(1794 \mathrm{mg} \mathrm{L}^{-1}\right)$ and $\mathrm{Fe}\left(197 \mathrm{mg} \mathrm{L}^{-1}\right)$. A plot of $\log \mathrm{EC}$ and $\mathrm{pH}$ for the water samples is presented in Fig. 14. The plot clearly shows two groups that can be identified by the direction of arrows. The one group is of samples showing a decrease in $\mathrm{pH}$, largely samples that showed a tendency towards acid generation while the other group showed an increase in $\mathrm{pH}$ and constituted mainly of samples collected at borehole depths of less than $1 \mathrm{~m}$ and some surface water samples as well.

\section{Water Classification}

Trilinear plots (Piper diagrams) are used in hydrogeological studies as an effective graphical means of displaying data that contain three dominant components, each of which is typically expressed as a percentage of the total of the three. Analyses of ground water samples can be plotted on a trilinear plot to show relative percentages of cations (e.g., $\mathrm{Na}^{+}$, $\mathrm{K}^{+}, \mathrm{Ca}^{2+}$, and $\left.\mathrm{Mg}^{2+}\right)$ and anions (e.g. $\mathrm{Cl}^{-}, \mathrm{SO}_{4}{ }^{2-}$ and $\left(\mathrm{HCO}_{3}{ }^{-}+\mathrm{CO}_{3}{ }^{--}\right)$). Multiple samples can be plotted on the same trilinear plot, and trends, groupings, and mixing patterns can easily be observed. Once plotted, multiple samples can then be classified or grouped together. A piper diagram in Fig. 15 shows the classification of the borehole and surface waters at the site. 


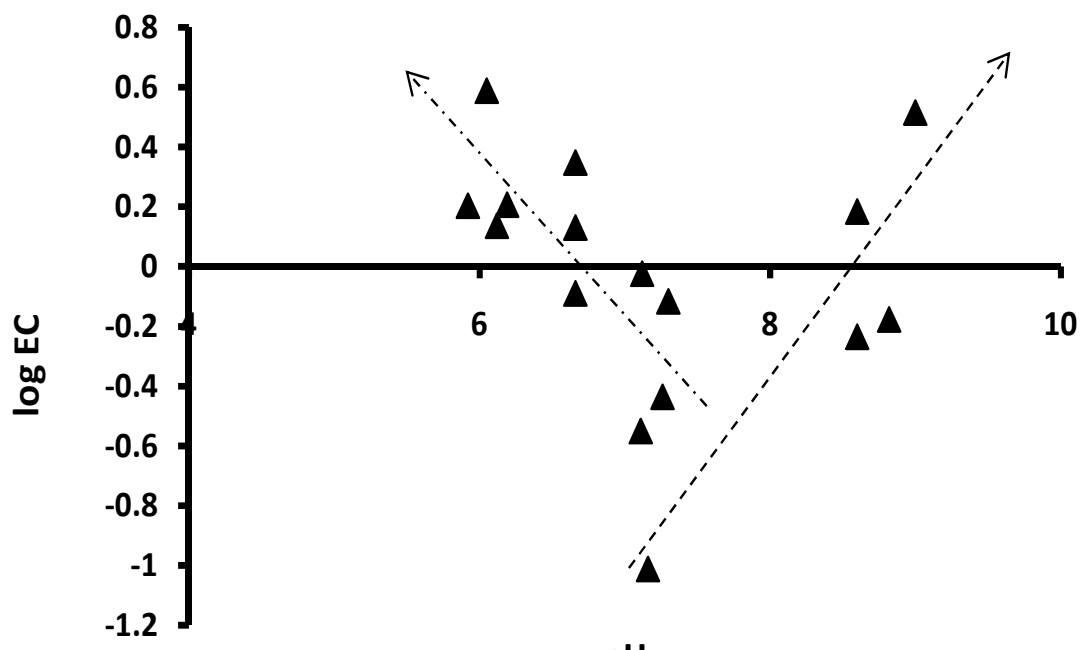

pH

Fig. 14. EC-pH relationship of the borehole and surface water samples.

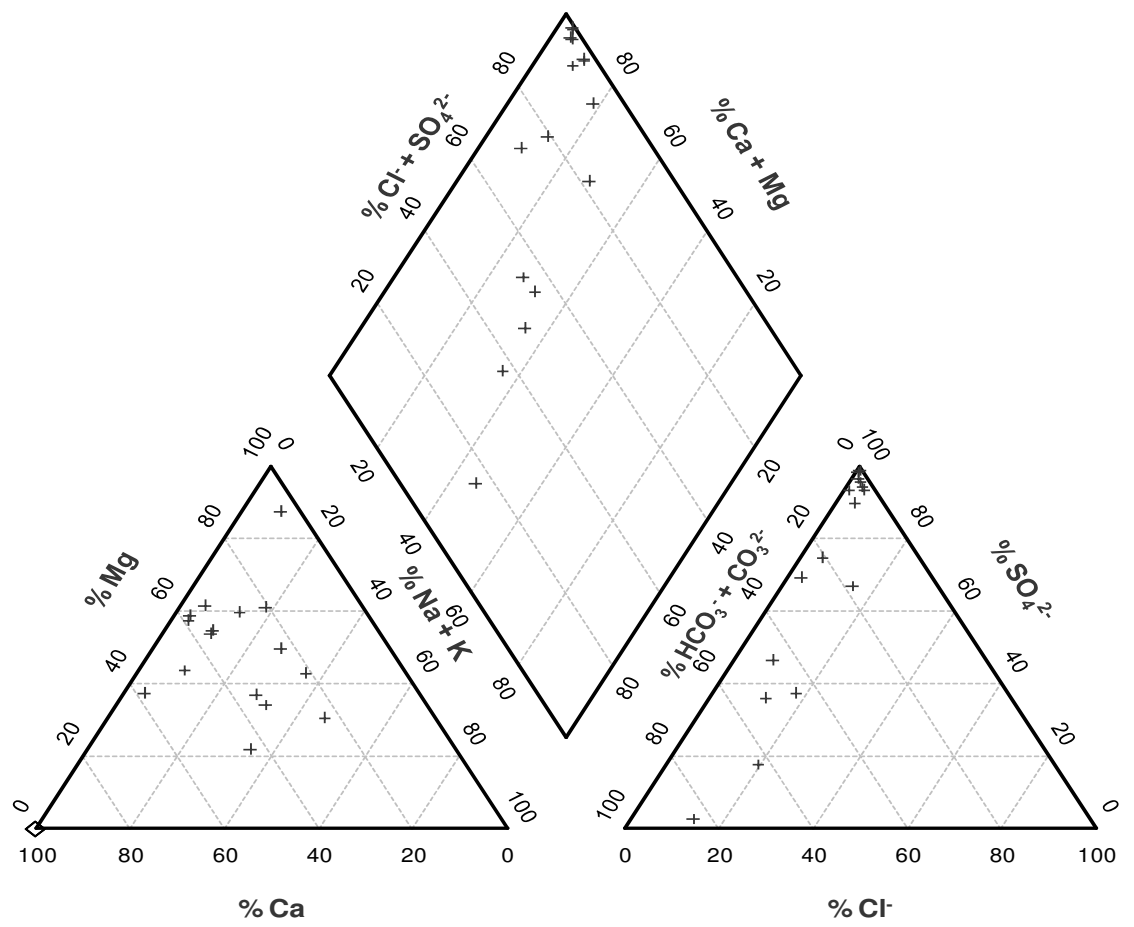

Fig. 15. Distribution of $\%\left(\mathrm{Na}^{+}+\mathrm{K}^{+}\right), \% \mathrm{Mg}^{2+}$, and $\% \mathrm{Ca}^{2+}$ and $\% \mathrm{Cl}^{-}, \% \mathrm{SO}_{4}^{2-}, \%\left(\mathrm{HCO}_{3}^{-+}\right.$ $\mathrm{CO}_{3}^{2-}$ ) depicting the classification of borehole and surface waters. 
The cations $\mathrm{Na}^{+}, \mathrm{K}^{+}, \mathrm{Ca}^{2+}$ and $\mathrm{Mg}^{2+}$ were plotted on the left triangle and the anions $\mathrm{Cl}^{-}, \mathrm{SO}_{4}{ }^{2-}$ and $\left(\mathrm{HCO}_{3}{ }^{-}+\mathrm{CO}_{3}^{2-}\right)$ were plotted on the right triangle. Points on the anion and cation diagrams were projected upward to where they intersect on the diamond. The data plotted into two distinct groups: (1) the surface water samples plotted towards the increasing proportions of (bicarbonate + carbonate) anions and (2) the borehole samples plotted towards increasing proportions of the sulphate anion. Both surface and groundwater had high proportions of calcium and magnesium which could mainly be from liming. The grouped data indicated that the borehole waters had increased sulphate content, largely due to the onset of pyrite oxidation at greater depths. The water classification revealed the following facies: Ca-Mg sulphate type for the borehole water and Ca-Mg sulphatebicarbonate for the surface waters.

\section{Conclusion}

The studies reported here have shown the potential of occurrence of acidic leachates from mining environments with a predominantly sulphidic (particularly pyritic) geological ore composition. Disturbance of old waste dumps by processes such as reprocessing has been shown to lead to an increased potential for release of pollutants. Column leaching was useful for simulating the real environmental scenario likely to occur in tailings impoundments. There was evidence of release of pollutants and their likely interaction with the soil matrix during percolation and downward leaching, and their subsequent ingress into groundwater systems. Water quality was shown to be influenced by plumes emerging from such leaching processes. The results pointed to loss of buffering capacity over prolonged leaching, leading to release of pollutants from the host ores.

Interventions to curtail AMD e.g. by liming have been shown to come short in some cases, particularly where there is no systematically worked out match between the sulphidic composition and the amount of lime to be applied as was demonstrated for the coal mining case. In this case, acid base accounting proved to be an excellent first-order tool and early warning system to determine whether mine waste has the potential to form acidic drainage. It underscored the fact that, when evaluating the extent or likelihood of AMD, it is important to know the amount of hydrogen ions remaining in solution after the buffering is complete.

While liming could be an important intervention for most divalent metals, the likelihood of some elements within the constituent ore, particularly the oxy-anions, to be leached to the receiving water is high. Thus, other interventions have to be considered alongside liming in attempting to curtail AMD and its attendant pollutants.

Variability of the composition of waste material, particularly due to prior metallurgical processes and disposal methods, has been shown to contribute significantly to the variability in the quality of impacted water. Thus, even within the same locality the water quality may differ significantly. Features such as efflorescent salts have also been assessed so as to understand their contribution to the overall quality of water. Their role as evaporation barriers has been shown to enable them to have a high capacity to store various pollutants contained in the shallow groundwater which are precipitated as the water exudes to the surface. As such, it has been possible to infer their impact on receiving water in the event of dissolution during reprocessing activities and flush rain showers. 
Further work still needs to be conducted with respect to the detailed solid-liquid interactions occurring in the tailings. As these interactions are complex, geochemical modelling techniques could be applied to simulate the reaction of various components in the host ores with the pore solution as it flushes through the material. This could shed some light regarding aspects such as the observed reduction in Fe concentrations over the duration of leaching likely due to precipitation, a phenomenon that usually occurs with coprecipitation of other metals but which was not the case in this instance. For the decommissioned coal operation, some kinetic tests need to be performed on the samples to assess the rate of oxidation of pyrite in the area. This test is usually done on samples with a net neutralising potential value between -20 and $20 \mathrm{~kg} \mathrm{t}^{-1} \mathrm{CaCO}_{3}$ as it is a grey range of uncertainty whereby the sample may or may not generate acidity. The test utilises humidity cells to simulate the weathering process in weekly cycles for a period of about 20 weeks. At the end of each week, the $\mathrm{pH}$ of the sample is measured and the weathered products are collected in the leach process.

Other interventions can be considered as rehabilitation strategies that could support the liming effort for the decommissioned coal opencast operation. These include use of reactive barriers constructed to cut across the general flow path of the shallow plume as it exits the block under study. This will enable the pollutants in the water to be trapped and thus clean up the water exiting into the natural streams outside the block. Reactive barriers can be made of clay, concrete or other cost-effective materials with a capacity to adsorb pollutants. Another option would be using a phytoremediation strategy. Phytoremediation is a technique that involves the use of metal hyper-accumulating plants to remove metals from contaminated soils. It is cost-effective and environmentally-friendly. It makes use of the capacity of plants to form phytochelatins in roots by releasing organic acids that dissolve metals, making them bioavailable and transporting them to shoots. Hyperaccumulators are conventionally defined as species capable of accumulating metals at levels 100 -fold greater than those typically measured in common non-accumulator plants. This would be important than the grass cover currently being used considering the elevated concentrations observed in the spoil material. Hyperaccumulators can be used for phytomining which is a process whereby a metal-hyperaccumulating plant species is grown on polluted soils and the biomass harvested and burned to produce a bio-ore.

\section{Acknowledgement}

The author would like to acknowledge the following organizations for financial support towards this work: the National Research Foundation of South Africa, the Carnegie Corporation and the Friedel Sellschop Foundation. The contribution by the following people is also acknowledged: Prof. E. M. Cukrowska, Prof. T. S. McCarthy, Prof. L. K. Chimuka, I. M. Weiersbye, E. N. Bakatula, L. Maku, S. Sotyingwa, I. Khumalo, R. Repinga and B. P. Camden-Smith.

\section{References}

Allen, H. E., Perdue, E. M. and Brown, D. S. (1993). Metals in groundwater, Lewis Publishers, Chelsea, London, U. K. 
Bakatula, E.N., Tutu, H., Cukrowska, E.M. and Weiersbye, I.M. (2008). Cyanide and cyanide complexes in gold-mine polluted land, Proceedings of the Mine Closure Seminar, ISBN 978-0-9804185-6-9, Johannesburg, South Africa, 14-17 October 2008

Blowes, D. W., Ptacek, C.J., Benner, S. G., Waybrant, K. R., Bain, J. G. (1998). Permeable reactive barriers for the treatment of mine tailings drainage water, Proceedings of the International Conference and Workshop on Uranium Mining and Hydrogeology, Freiberg, Germany, September, 1998, Vol.2, 113-119

Clesceri, S., Greenberg, E. and Rhodes, R. (Ed(s).). (1998). Standards methods for the examination of water and wastewater. (20th edition), American Public Health Association, Washington DC, USA

Davidson, C. (2003). Catchment diagnostic framework for the Klip River catchment, Vaal barrage, October 1998 - September 1999, MSc Research Report submitted to the University of the Witwatersrand, Johannesburg

Ehrlich, H. L. (1996). Geomicrobiology, Dekker, New York, 719

Forstner, U. and Wittmann, G. T. W. (1976). Metal accumulations in acidic waters from gold mines in South Africa. Geoforum 7, 44 - 49

Funke, J. W. (1990). The water requirements and pollution potential of South African gold and uranium mines, Water Research Commission Report, ISBN 0947447 27X, Pretoria, South Africa

Geldenhuis, A.J., Bell, F.G., (1998). Environmental Geology 103, 345

Hermond, H.F., and E.J. Fechner-Levy. (2000). Chemical fate and transport in the environment, Academic Press, San Diego, USA.

Jambor, J. L. (1994). Mineralogy of sulfide-rich tailings and their oxidation products. In: Jambor, J. L. and Blowes, D. W. (eds.): Short Course Handbook on Environmental Geochemistry of Sulfide Mine Waste. Mineralogical Association of Canada, Nepean, Vol.22, 59-102

Jambor, J. L. and Blowes, D. W. (1998). Theory and applications of mineralogy in environmental studies of sulfide-bearing mine waste. In: Cabri, L. J. and Vaughan, D. J. (eds.): Short Course Handbook on Ore and Environmental Mineralogy. Mineralogical Association of Canada, Nepean, Vol. 27, 367-401

Jones, G. A., Brierley, S. E., Geldenhuis, S. J. J. and Howard, J. R. (1988). Research on the contribution of mine dumps to the mineral pollution load in the Vaal Barrage, Report to the Water Research Commission, WRC Report No. 136/1/89, Pretoria, South Africa

Langmuir, D. (1997). Aqueous environmental geochemistry. Prentice Hall, Upper Sadle River, N. J.

Levinson, A. A. (1974). Introduction to exploration geochemistry, 2nd edn, Photopress Inc., USA, 689-697

Marsden, D. D. (1986). The current limited impact of Witwatersrand gold-mine residues on water pollution in the Vaal River system. Journal of the South African Institute of Mining and Metallurgy, 86, 481-504

McCarthy, T.S. (2008). Coal mining plans put fresh water at risk, Sunday Independent newspaper, Accessed on 10 February 2008, Available from http://www.iol.co.za 
Morin, A. K. and Hutt, N. M. (1997). Environmental geochemistry of mine site drainage. Practical theory and case studies, MDAG Publishing, Vancouver, Canada, 333

Moses, C. O., Nordstrom, D. K., Herman, J. S. and Mills, A. L. (1987). Aqueous pyrite oxidation by dissolved oxygen and by ferric iron. Geochimica et Cosmocimica Acta, Vol. 51, 1561-1571

Mphephu, N. F. (2004). Geotechnical environmental evaluation of mining impacts on the Central Rand. PhD Thesis submitted to the University of the Witwatersrand, Johannesburg

Naicker, K., Cukrowska, E. and McCarthy, T. S. (2003). Acid mine drainage arising from gold mining activities in Johannesburg, South Africa and environs, Journal of Environmental Pollution 122, 29-40

Nordstrom, D. K., Jenne, E. A. and Ball, J. W. (1979). Redox equilibria of iron in acid mine waters. In: Jenne, E.A. (Ed.): Chemical modeling in aqueous systems. Am. Chem. Soc. Symp. Washington, D.C., Series 93, 51-79

Nordstrom, D. K. and Alpers, C. N. (1999). Geochemistry of acid mine waste. In: Plumlee, G. S. and Logsdon, M. J. (Eds.), Reviews in Economic Geology, The environmental geochemistry of ore deposits. Part A: Processes, techniques, and health issues, Vol. 6A, 133-160

Pinetown, K.L., Ward, C.R., van der Westhuisen, W.A. (2007). International Journal of Coal Geology 70, 166

Prevost, X.M. (2004). South African reserves and the Minerals Act. Coaltrans South Africa, Cape Town, South Africa

Pulles, W. (2003). Mining Weekly, January 24-30, 2-3

Rosner, T. and van Schalkwyk, A. (2000). The environmental impact of gold mine tailings footprints in the Johannesburg region, South Africa, Bull. Eng. Geol. Env., Vol. 122, 137-148

Rosner, T., Boer, R., Reyneke, R., Aucamp, P. and Vermaak, J. (2001). A preliminary assessment of pollution contained in the unsaturated and saturated zone beneath reclaimed gold-mine residue deposits, Water Research Commission Report No. 797/01/01, Pretoria, 210

Schwertmann, U. (1985). The effect of pedogenic environments on iron oxide minerals. In: Advances in Soil Science, Vol. 1, Springer-Verlag, New York, USA

Scott, R. (1995). Flooding of Central and East Rand goldmines: an investigation into controls over the inflow rate, water quality and the predicted impacts of flooded mines. Water Research Commission Report No. 224/1/72, Pretoria

Singer, P. C. and Stumm W. (1970). Acid mine drainage: rate determining step, Science 167, 1121-1123

Skousen, J., Simmons, J., McDonald, L.M., Ziemkiewicz, P. (2002). Acid-Base Accounting to Predict Post-Mining Drainage Quality on Surface Mines, J. Environ. Qual. 31, 20342044

Tutu, H. (2006). Determination and geochemical modelling of the dispersal of uranium in gold-mine polluted land in the Witwatersrand Basin. Ph.D thesis to the University of the Witwatersrand, Johannesburg 
Tutu, H., T. S. McCarthy, E. M. Cukrowska. (2008). The chemical characteristics of acid mine drainage with particular reference to sources, distribution and remediation: the Witwatersrand Basin, South Africa, as a case study, Applied Geochemistry 23: 36663684

Usher, B.H., Cruywagen, L.M., de Necker, E. and F.D.I. Hodgson, F.D.I. (2003), On-site and Laboratory Investigations of Spoil in Opencast Collieries and the Development of Acid-Base Accounting Procedures, Water Research Commission, WRC Report No. 1055/1/03, ISBN 1-77005-053-1, Vol. 1., pp 3, 9, 11, 13, 25

Zielinski, R. A., AsherBolinder, S., Meier, A. L., Johnson, C. A. and Szabo, B. J. (1997). Natural or fertilizer-derived uranium in irrigation drainage: A case study in southeastern Colorado, U. S. A. Applied Geochemistry 12(1), 9-21 


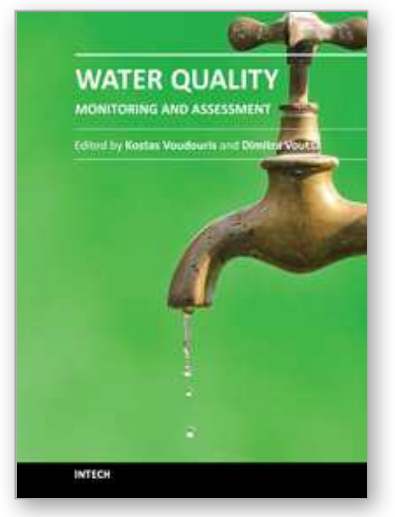

\author{
Water Quality Monitoring and Assessment \\ Edited by Dr. Voudouris
}

ISBN 978-953-51-0486-5

Hard cover, 602 pages

Publisher InTech

Published online 05, April, 2012

Published in print edition April, 2012

The book attempts to covers the main fields of water quality issues presenting case studies in various countries concerning the physicochemical characteristics of surface and groundwaters and possible pollution sources as well as methods and tools for the evaluation of water quality status. This book is divided into two sections: Statistical Analysis of Water Quality Data;Water Quality Monitoring Studies.

\title{
How to reference
}

In order to correctly reference this scholarly work, feel free to copy and paste the following:

Hlanganani Tutu (2012). Mining and Water Pollution, Water Quality Monitoring and Assessment, Dr. Voudouris (Ed.), ISBN: 978-953-51-0486-5, InTech, Available from: http://www.intechopen.com/books/water-qualitymonitoring-and-assessment/mining-and-water-pollution

\section{INTECH}

open science | open minds

\section{InTech Europe}

University Campus STeP Ri

Slavka Krautzeka 83/A

51000 Rijeka, Croatia

Phone: +385 (51) 770447

Fax: +385 (51) 686166

www.intechopen.com

\section{InTech China}

Unit 405, Office Block, Hotel Equatorial Shanghai

No.65, Yan An Road (West), Shanghai, 200040, China 中国上海市延安西路65号上海国际贵都大饭店办公楼 405 单元

Phone: +86-21-62489820

Fax: +86-21-62489821 
(C) 2012 The Author(s). Licensee IntechOpen. This is an open access article distributed under the terms of the Creative Commons Attribution 3.0 License, which permits unrestricted use, distribution, and reproduction in any medium, provided the original work is properly cited. 